\title{
Javna polemika Stipe Šuvara i Šime Đodana iz 1969. kao primjer borbe ideja u (trans) nacionalnom kontekstu
}

\author{
MARINO BADURINA \\ Rijeka, Hrvatska \\ mbadurina90@gmail.com
}

\begin{abstract}
U radu se razmatraju povod, tijek i sadržaj intelektualne i političke debate između Stipe Šuvara i Šime Đodana koja se odvijala tijekom 1969., u uvjetima društveno-političkih, kulturnih i ekonomskih previranja u tadašnjoj socijalističkoj Hrvatskoj i Jugoslaviji. Glavno pitanje koje se eksplicitno i implicitno provlačilo kroz debatu bilo je: „Je li Hrvatska u Jugoslaviji eksploatirana?" No ta je rasprava bila višeslojna i kompleksnija od toga. U njoj su se autori dotakli i međuodnosa nacionalizma i međunarodne ekonomske integracije unutar Jugoslavije, kao i integracije Jugoslavije sa svijetom, odnosa ekonomije i kulture, emocionalnih i racionalnih argumenata u političkoj i ekonomskoj sferi, nacionalizma i demografije, modernizacije i nacionalne emancipacije, međudjelovanja procesa u istočnom, socijalističkom lageru i na Zapadu te konsekvencija koje bi Jugoslavija i jugoslavensko društvo iz toga trebali povlačiti. U takvu složenijem iščitavanju njihove suprotstavljene pozicije (borba ideja) ne mogu se svoditi na dihotomiju socijalizam - nacionalizam i hrvatstvo - jugoslavenstvo.
\end{abstract}

Ključne riječi: Jugoslavija; Hrvatska; Šime Đodan; Stipe Šuvar; nacionalizam; socijalizam; globalizam

Globalizacija je ideja smanjivanja svijeta i jačanja svijesti o njegovoj cjelini. Premda je „prva” globalizacija bila u središtu zanimanja i socijalnih teoretičara XIX. stoljeća (Comte, Saint-Simon, Marx), šire globalizirajuće spoznaje bile su tehnički omogućene tek u drugoj polovini XX. stoljeća, a možemo reći da je sociološka analiza „svijeta” izravnije počela tek 60 -ih godina. ${ }^{1}$ Uostalom, i sam termin „globalizacija”, premda starijega datuma, u široku upotrebu ulazi u istom desetljeću, a vrhunac globalizacijskih debata bit će krajem 80-ih i početkom 90 -ih godina prošloga stoljeća. ${ }^{2}$ Pritom je važno osvijestiti da koliko je socioekonomska stvarnost podloga nastanku i diseminaciji ideja, toliko su i ideje one koje imaju moć tu stvarnost transformirati. Radi se o stalnom

\footnotetext{
1 ROBERTSON, Globalization: Social Theory and Global Culture, 10.

2 KALUĐEROVIĆ, „Poimanje globalizacije”, 15.
} 
odnosu međudjelovanja. Dio iste pravilnosti jest i zakon akcije i reakcije. Neki će autori tumačiti da su globalizacijski procesi često, posebno u nerazvijenijim dijelovima svijeta kakav je bila npr. jugoistočna Europa, kao obrambenu reakciju rađali nacionalizam, i obrnuto. ${ }^{3}$ Nema krajnjega odgovora na dilemu koliko je nacionalizam samo posljedica, a koliko uzrok društvenih, ekonomskih i političkih promjena. ${ }^{4}$ Pitanje je i je li opravdano artificijelno razdvajati politiku, ekonomiju i kulturu. Nije li i ekonomija dio kulture, nisu li i ekonomska pitanja par excellence politička, pa i idejna? ${ }^{5}$ Štoviše, društvo i ekonomija stvoreni su u kulturi i reproduciraju se upravo kroz kulturalne prakse i obrasce. ${ }^{6}$ Oni tako postaju neodvojivi od identiteta.

Čitavo hladnoratovsko razdoblje (1945. - 1990.) općenito uzevši nije najprohodnije za promatranje osjetljivoga međuodnosa partikularizma i univerzalizma. Svi politički zahtjevi koji su se oslanjali na ovo prvo bili su smatrani „nižima” u odnosu na one koji su proklamirali ovo drugo. ${ }^{7}$ Nacionalizam se smatrao dežurnim smetalom, mnogo je važnije bilo odrediti se kao liberal ili konzervativac, socijalist (eurokomunist) ili dogmat (staljinist), zapadnjak ili sovjetofil (rusofil) itd. Lakše je bilo objasniti svoju ideološku poziciju i ekonomski interes nego raspredati o etničkim, jezičnim i ostalim kulturnim razlikama. Pa ipak, ispod velikih ideoloških narativa (liberalnih ili socijalističkih) stalno su plutale i jasne nacionalne agende. ${ }^{8}$

Socijalistička kolektivistička, ali i (inter)nacionalistička društva čak su ostavljala više prostora za raspravu o/u nacionalnim kategorijama od zapadnih, liberalnih. Odnos „eksploatatora” i „eksploatiranoga” u socijalističkoj ideologiji uvijek je mogao biti upotrijebljen, pa i u međunacionalnim razmiricama. Uvriježeni stav da samo velike kapitalističke nacije mogu eksploatirati male „proleterske nacije" bio je relativiziran; dapače, manjinski (ili defenzivni) nacionalizam mogao se pojaviti u okviru svakoga ekonomskog sistema, pa i socijalističkog. ${ }^{9}$ Period 70-ih i 80-ih godina donio je najveći rast svjetske trgovinske razmjene, čemu su poseban doprinos dale zemlje $u$ razvoju. No, $u$ tom periodu svijet je postao $i$ financijski međuovisan više nego ikad prije, rast financijske razmjene (financijalizacija) uskoro će nadmašiti rast one trgovinske. ${ }^{10}$ To će svjetsku ekonomiju i pomaknuti prema neoliberalnome modelu, a socijalističke ekonomije ostat će trajno zarobljene u pitanjima kako povećati materijalnu proizvodnju, izvoz itd. U zemljama Trećega svijeta postojala je istovremeno glad, potreba za kapitalom, znanjem, investicijskim i potrošačkim dobrima, ali i strah od nametanja društvenih modela velikih sila. Jugoslavija, u kojoj su društvene i ekonomske reforme

\footnotetext{
3 ČALIĆ, Jugoistočna Evropa: globalna historija, 500.

4 ANDERSON, States and Nationalism in Europe Since 1945, 8.

5 BAYLY, The Birth of the Modern World, 1-2, 65, 136.

6 HONGTU, „The return of the history of ideas - Observations on the evolution of research paradigms in the history of ideas", 142.

ANDERSON, States and Nationalism in Europe Since 1945, 12.

8 Isto, 13, 25.

9 Isto, 69; NAIRN, Faces of Nationalism: Janus Revisited, 22.

10 HARVEY, A Brief History of Neoliberalism, 33, 90.
} 
60-ih godina težile temeljitosti koja nije bila karakteristična za većinu ostalih socijalističkih zemalja, u svojoj je unutarnjoj strukturi osjećala višeslojnu napetost, želju za razvojem, za umrežavanjem sa svijetom, ali i za zadržavanjem posebnoga položaja, vlastitoga socioekonomskog, pa i političkog modela.

Primjer jedne unutarhrvatske i unutarjugoslavenske polemike s kraja 60ih godina, one između sociologa Stipe Šuvara i ekonomista Šime Đodana, koji su usto bili članovi vladajućega Saveza komunista, s glavnim pitanjem ekonomske eksploatacije Socijalističke Republike Hrvatske u Jugoslaviji, može poslužiti kao ogledalo nerazdvojne isprepletenosti društva i ekonomije, kulture i politike. Na drugoj strani ista polemika može se sagledati kao dobar primjer i podsjetnik na promišljanje prakse integracijskih procesa, bilo globalnih bilo jugoslavenskih, pod socijalizmom, posebno u njegovu reformskom razdoblju 60-ih i 70-ih godina.

Cilj je ovoga članka analizom sadržaja njihovih tekstova, bilo da se radi o tekstovima u kojima se izravno polemizira ili onima u kojima autori (posebno Đodan) šire tumače svoje stavove, prepoznati zbog kojih se sve faktora i elemenata sukob odigravao. Jesu li njihove ideje i stavovi bili samo njihovi ili, i u kojoj mjeri, dio kolektivne društvene (partijske i izvanpartijske) rasprave? Koji je i koliki bio njihov osobni, originalni doprinos tim raspravama? Početna je pretpostavka da ti odnosi svakako funkcioniraju na razinama mnogo složenijim od prostih binarnih opreka te da se ne mogu svoditi na sukob hrvatstva/nacionalizma (Đodan) i jugoslavenstva/socijalizma (Šuvar). Dapače, njihovi tekstovi i teze mogu poslužiti kao odraz brojnih drugih dinamičnih kontroverzi kroz koje se prelamaju uloge intelektualaca i političara, odnosi nacionalnoga i klasnoga, ekonomskoga nacionalizma i globalizma, tradicije i modernosti itd. Cilj je sve to, uz pomoć dijela arhivske građe i relevantne literature, uključujući i onu teorijsku, smjestiti u (trans)nacionalnu perspektivu 60-ih godina, kad se društvo ubrzano i osjetno mijenja, a svijest o globalnoj međuzavisnosti postaje sve jača. Naposljetku, Šuvara i Đodana, tj. njihove pozicije, želimo barem uzgred ukrstiti i s drugim političkim i intelektualnim osobnostima onoga vremena poput Vladimira Bakarića, Miloša Žanka, Petra Šegedina, pa čak i samoga Josipa Broza Tita, premda uz svijest da su i njihovi idejni sustavi, kao i kod svakoga, trajno nestabilni i fluktuirajući.

\section{Unutarnji kontekst - ideje iznad institucija}

Intelektualna rasprava stara je i uobičajena forma borbe ideja. Nominalno bi u toj vrsti debate snaga argumenata trebala zauzimati centralno mjesto. No previše je izvanjskih uvjeta i podražaja (društveni kontekst, predrasude, odnosi moći) koji su za opredjeljivanje često bitniji od same predmetne suštine. Naposljetku, isti argumenti različitim grupama i pojedincima nikad neće značiti isto. ${ }^{11}$ Ipak, jedan od mogućih puteva za intelektualnu povijest jest

\footnotetext{
11 ECHEVARRIA, Wars of Ideas and the War of Ideas, 5-6.
} 
nova akomodacija ili sjedinjavanje tzv. stare povijesti ideja (Arthur O. Lovejoy) s novom društvenom historijom, ali kroz veće „hvatanje” iznijansiranih povijesnih odnosa između ideja, tekstova i obrazaca mišljenja umjesto da se sve promatra isključivo kroz socijalne identitete i institucionalne pripadnosti onih aktera koje se s tim idejama, mislima i tekstovima povezuje. ${ }^{12} \mathrm{Cilj}$ takve intelektualne povijesti bio bi ideje sagledati šire od institucija u kojima one nalaze svoje pristaše i izbjeći jednosmjernu subordiniranost intelektualne povijesti krutom kontekstualizmu, relativizirati takvu analizu misli koja se uvijek promatra neodvojivo od političkih, profesionalnih, akademskih niša u kojima se izražavala. Štoviše, cilj je intelektualnu povijest emancipirati i od ambivalentnosti pojma „intelektualac” kao nekakve zasebne klase ili posebnoga društvenog tipa. Proizvodi uma, sadržaji misli i ideje rijetko su vezani za neku posebnu klasu. ${ }^{13}$ Zato bi i nas ovdje Stipe Šuvar i Šime Đodan zanimali više kao provodnici društvenih ideja koje su bile u optjecaju nego samo kao pripadnici određenih institucionalnih i organizacijskih okruženja (Savez komunista, Matica hrvatska, Sveučilište itd.).

Sami intelektualci tradicionalno su osjećali skepsu prema mogućnostima, snazi i utjecaju vlastitih ideja i djelovanja. Socijalistički intelektualci u toj vrsti malodušnosti proveli su dobar dio druge polovine XX. stoljeća. Oni su se osjećali kao ovan na brvnu nasuprot kojemu su uglavnom stajale razne birokratske strukture, čak i kad bi te strukture tvorile organizaciju radničkoga pokreta. ${ }^{14}$ Stoga je među njima s vremenom sve više jačalo uvjerenje da uloga socijalističkoga intelektualca nije iscrpljena njegovim pridruživanjem partiji, dapače da on podčinivši se političkim diktatima nikad ne može ispuniti svoju svrhu, služiti radničkoj klasi i pokrenuti društvenu energiju. ${ }^{15} \mathrm{~S}$ druge strane hladnoratovske rampe Friedrich Hayek, koji je socijalizam izjednačavao s protekcionizmom, a socijalističke ekonomiste s protekcionistima, intelektualce je tumačio kao organe koje je moderno društvo razvilo da bi preko njih širilo znanje i ideje, dok su njihova uvjerenja kao sito kroz koje bivaju propuštene sve nove ideje i koncepcije prije nego što dosegnu narodne mase. ${ }^{16}$ Iako je tako shvaćen protok ideja previše jednostran, svakako je točniji jedan drugi zaključak, da je za intelektualce uvijek bilo privlačnije operirati s načelnim planovima novoga društvenog poretka (velikim narativima) nego baviti se tehničkim detaljima i sitnim popravcima postojećega sustava. ${ }^{17}$ Za Hayeka je takva opreka između utopijskih vizija i realističnoga popravljanja postojećega vrijedila za odnos (novoga) socijalizma i (staroga) liberalizma, ali zapravo se ta vrsta napetosti uvijek javlja na relaciji staro - novo, čak i unutar istoga sistema. Revolucionar koji danas pobijedi, po prirodi stvari, već sutra postaje konzervativac. Takav razvoj uloge intelektualca nastojat ćemo promatrati i na primjeru ove polemike.

12 WICKBERG, „Intellectual History vs. Social History of Intellectuals”, 384.

13 Isto, 385-386.

14 THOMPSON, „Socialism and the Intellectuals”, 96.

15 Isto, 98.

16 HAYEK, „The Intellectuals and Socialism”, 19-21.

17 Isto, 28. 
Trajna ambivalentnost u odnosu s intelektualcima karakterizirala je i vladajuću Partiju u Jugoslaviji. Trzavice su postojale s inteligencijom unutar i izvan partijskih struktura. Šef hrvatskih komunista Vladimir Bakarić, čije su mnoge ideje i teze dominirale hrvatskom, pa i jugoslavenskom dnevnom politikom tijekom nekoliko desetljeća, prema mnogim je intelektualcima gajio podvojene osjećaje uvažavanja i nesnošljivosti, kao na kakvoj klackalici izmjenjivali su se periodi dijaloga i periodi sukoba. ${ }^{18}$ Odnos Partije i intelektualaca u drugoj polovini 60 -ih godina, u uvjetima sve veće liberalizacije, bio je reaktualiziran, vrh Partije to je pratio uz svijest da je potrebno izgraditi novi sistem odnosa, ali da među intelektualcima ima previše onih „koji brljave i - da se to desilo prije rata svi bi glavačke letjeli iz Partije" ${ }^{19}$ U novim uvjetima, međutim, Partija najčešće nije zaoštravala pitanje njihove odgovornosti, osim u iznimnim slučajevima, npr. donošenja Deklaracije o nazivu i položaju hrvatskog književnog jezika iz 1967., premda ni „ti ljudi nisu neprijatelji socijalizma, ali su prešli granice”. ${ }^{20}$ Doduše, Partija taj „novi sistem odnosa” nikad neće do kraja izgraditi, nepovjerenje će u nadolazećem periodu samo jačati. No u ovom razdoblju, 1968./1969., sve se još uvijek činilo mogućim. Političke strukture vjerovale su da usmjeravaju i kontroliraju prostor ideja, intelektualci su vjerovali da guraju i potiču društvene i političke promjene. Neko vrijeme činilo se da takav odnos tolerantno funkcionira. Ali čak i kad su naizgled išli istim putem, koplja su se mogla lomiti oko pitanja - tko je konj, a tko jahač?

\section{Šime Đodan i Stipe Šuvar - „relativno nejaki pojedinci”}

Povijest ideja je i povijest masa, a ne samo elita, tekstove potpisane imenom i prezimenom možemo promatrati samo kao instance nekih ideja koje se mogu pronaći i na mnogim drugim mjestima. Dapače, mnoge tendencije u danom vremenu jasnije su u djelima pisaca i stvaratelja u drugim i trećim ešalonima nego kod onih najpoznatijih i najisturenijih. ${ }^{21}$ Upravo su zato i Stipe Šuvar i Šime Đodan možda zanimljiviji iz pozicije te 1969., dok su još bili, premda ne anonimni, ipak relativno nepoznati pojedinci, nego bilo kada kasnije. Šime Đodan tada je bio docent na Pravnom fakultetu, a pored toga član Upravnoga odbora i gospodarski tajnik Matice hrvatske (1967. - 1971.). Stipe Šuvar bio je istraživač, a potom ravnatelj u Agronomskom institutu u Zagrebu (1965. - 1968.). U javnosti je tih godina istupao sa stručnim sociološkim, ali i publicističkim člancima, posebno kao glavni i odgovorni urednik časopisa Naše teme: časopis za društvena pitanja (1963. - 1972.). Krajem 60-ih Šuvar i Đodan bili su još uvijek mladi, ali ujedno dovoljno iskusni i samouvjereni pu-

18 Za odnos Bakarića prema nacionalno orijentiranim oporbenjacima, ali i tzv. lijevim kritičarima u navedenom razdoblju vidi: MUJADŽEVIĆ, Bakarić. Politička biografija, 265-274.

19 HR-HDA-1002-OFVB, kut. 69, „Razgovor dr. V. Bakarića sa dopisnicima RTV i Vjesnika u inozemstvu /stenogr/, 18. 2. 1969.", str. 16.

20 Isto.

${ }^{21}$ WICKBERG, „Intellectual History vs. Social History of Intellectuals”, 393. 
blicisti, željni i smjelijih, provokativnijih teza, spremni i na polemičke izlete. Nisu se zadovoljavali samo postojećim, htjeli su dati i osobni pečat.

Đodanove teze, prije svega - ali ne i isključivo - ekonomske, između 1968. i kraja 1971. varirale su od općeprihvaćenih preko blago kontroverznih i distinktivnih do opasnih i inkriminirajućih. Paralelno s političkom situacijom radikalizirale su se njegove teze i on sam. No kasnije, kad nakon prosinca 1971. započne širi politički obračun s „nacionalističko-separatističkim” snagama u Hrvatskoj, sve će biti strpano u isti koš. Tematski, Đodan će biti optužen da je od samoga početka pisao u duhu teza o Jugoslaviji kao tamnici Hrvatske, o pljački Hrvatske, raspaljivanjem mržnje prema Srbiji i separatističkim koncepcijama hrvatske državnosti. Kao ogledni primjeri navodit će se niz Đodanovih članaka: „Problem razdiobe u našem društvu” (Kolo, br. 3, 1968.), „Gospodarska reforma i izbor optimalnog modela rasta” (Kolo, br. 4, 1968.), „Prilog razmatranju predloženih izmjena Ustava SFRJ” (Kolo, br. 11, 1968.), „Aktualni gospodarski položaj Zagreba” (Kritika, br. 13, 1970.), „Ustavni amandmani i problemi jedinstvenog tržišta” (Kolo, br. 4, 1971.), "Gospodarsko-politički uzroci emigracije iz Hrvatske” (Hrvatski tjednik, 23. 4. 1971.), „Gospodarski položaj Hrvatske”, (Kritika, br. 17, 1971.) i „Nacionalno i klasno kroz ekonomsku bit suvereniteta Hrvatske” (Studentski list, br. 22, 26. 10. 1971.). ${ }^{22}$ Glavni krimen intelektualaca u Matici bio je način [istaknuo M. B.] prezentacije činjenica i podataka, ne ulazeći u njihovu točnost, i cilj, koji je bio da se „temperatura u odnosima Hrvatska-Srbija [...] želi podizati po svaku cijenu i svim sredstvima, mnogi članci sadrže poluistine, ili izolirane činjenice, izdvojene iz konteksta objektivnih i subjektivnih okolnosti, a namjerno su prezentirane samo zato da se hrvatsko-srpski odnosi što više zatežu i kompliciraju”. ${ }^{23}$ Upadljivo, u ovoj informaciji nije naveden nijedan Đodanov članak iz 1969., uključujući i one iz polemike sa Šuvarom. Tome možda ne treba tražiti neke posebne uzroke, razlog može biti naprosto brzina sastavljanja takvih pregleda, naime od prosinca 1971. do siječnja 1972. u vrlo kratkom roku trebalo je pripremiti preliminarne inkriminirajuće materijale, pa analitičari možda i nisu imali vremena čitati više desetaka kartica, brojne teze, podatke i brojke koje su Đodan i Šuvar u svojoj polemici razmijenili. Uostalom, Đodan je plodnom produkcijom svojih ostalih tekstova ionako dao i više nego dovoljno „štofa” za konstruiranje optužbi. Iako je 1968. počeo s blažim tezama i formulacijama (tada još nije govorio o „pljački Hrvatske”), one su ipak od početka bile dovoljno konkretne, kao npr. kad je prigovarao federaciji da prevelike iznose prikuplja za gradnju novih objekata u Srbiji, Ma-

22 HR-HDA-1567-MH, kut. 113, „Informacija 'O nacionalističko-separatističkom djelovanju Matice hrvatske kroz listove i časopise'”, str. 11-13, 17-21, 34, 38. Napomena: U arhivskom fondu nema podataka tko je izradio ovu informaciju, ali s obzirom na to da je u razdoblju nakon 21. sjednice Centralnoga komiteta Saveza komunista Jugoslavije u prosincu 1971. nositelj svih aktivnosti protiv Matice hrvatske bio prvenstveno Republički sekretarijat za unutrašnje poslove Hrvatske, može se pretpostaviti da je i ovaj pregled iste geneze i namijenjen za istu svrhu, gradnju inkriminirajućih optužbi protiv prvaka Matice hrvatske.

23 Isto, str. 24. 
kedoniji i Crnoj Gori, a zanemaruje mnoge isplativije privredne djelatnosti, poput turizma. Proizvodne odnose u Jugoslaviji on je definirao kao još uvijek „državno-kapitalističke”, a ne „asocijativno-samoupravne socijalističke”. ${ }^{4}$ Potom, on je bio jedan od glavnih pozivatelja „masa” u politiku, posebno se zalagao za omasovljenje Matice hrvatske („sa 100.000 članova”), koja je prije bila samo elitna institucija. ${ }^{25}$ Termin „radnička klasa” vezao je uz nacionalnu atribuciju - „radnička klasa Hrvatske” ili „hrvatski udruženi proizvođači”, koji se ne mogu složiti s time da se njihov višak rada administrativnim odlukama otuđuje, dok se većina kapitala koncentrira u Beogradu, saveznim bankama, reeksportnim poduzećima itd. ${ }^{26} \mathrm{~S}$ druge strane tvrdio je da nije ekonomski separatist, nego za „jedinstveno i potpuno homogeno jugoslavensko tržište i jugoslavensku podjelu rada s čime će se razbiti otvorena tendencija nekih republika ka autarhiji i pokušaj da se vlastiti razvoj bez razumijevanja širih interesa prebaci na tuđi račun". ${ }^{27}$ Drugim riječima, Đodan je očekivao da bi pod tržišnim (samoupravnim) zakonitostima hrvatska ekonomija zbog svoje snage i potencijala trebala više profitirati, pa možda i dominirati, na jugoslavenskom planu. Optužbe za ekonomski nacionalizam on je težio preduhitriti kazavši da su upravo republičke autarhije „izraz ekstremnog ekonomskog nacionalizma iz kojega izniču svi ostali nacionalizmi kao refleksije toga, najopasnijeg nacionalizma". ${ }^{28}$ Sva ta intelektualna rabota odvijala se na fonu uvjerenja da intelektualci tada - bilo da su kritički raspoloženi članovi Saveza komunista kao npr. Đodan ili Marko Veselica bilo da su nominalno izvan Partije, no i dalje socijalistički orijentirani - zapravo imaju ulogu pomaganja službenoj liniji Saveza komunista, da ju brane, pa i usmjeravaju, i s nacionalne i sa socijalne strane. ${ }^{29}$ Oni ta dva pola i nisu jasno razdvajali, novu „socijalnu revoluciju” shvaćali su neodvojivo od nacionalnoga preporoda. Zato je i moguć raskorak u vrednovanju uloge koju su npr. Đodan i Veselica odigrali u sklopu studentskih gibanja na Zagrebačkom sveučilištu u lipnju 1968., kad su na skupu studenata istupili zajedno s profesorima kao što su Vanja Sutlić, Gajo Petrović, Milan Kangrga, Slavko Macarol i dr. Njihovo tumačenje bilo je da su na taj buntovni skup nastojali djelovati umirujuće, konstruktivno, uvjeriti studente da korjenite društvene promjene može voditi i Savez komunista kroz borbu za samoupravljanje te da su upravo oni odvratili studente od izlaska na ulice, dok je s druge strane Gajo Petrović okarakterizi-

24 ĐODAN, „Problemi razdiobe u našem društvu”, 196.

25 BRLEKOVIĆ, „Članstvo Matice hrvatske u prošlosti i sadašnjosti”.

26 ĐODAN, „Gospodarska reforma i izbor optimalnog modela rasta”, 305-306.

27 Isto, 307.

28 Isto.

29 U travnju 1969. na sastanku delegacije Matice hrvatske (Hrvoje Iveković, Šime Đodan, Vlatko Pavletić, Petar Šegedin, Grgo Gamulin, Danilo Pejović) i delegacije Centralnoga komiteta Saveza komunista Hrvatske (Miko Tripalo, Jure Bilić, Dušan Bilandžić) Tripalo je dao punu podršku Matici, obećao i financijsku pomoć od 300 milijuna dinara, a matičari su pritom rekli da su Deklaracijom o jeziku pomogli hrvatskom partijskom rukovodstvu. Vidi: BILANDŽIĆ, Povijest izbliza, 78. 
ran kao vođa „zagrebačkog ultralijevog ekstremističkog pokreta” ${ }^{30}$ Petrović je pak dao potpuno oprečnu interpretaciju po kojoj su upravo Đodan i Veselica jedini istupali ekstremistički, vatreno i zapaljivo, napavši „kočničare” u najvišim partijskim i državnim vrhovima, uz standardni repertoar o eksploataciji Hrvatske, ravnopravnosti itd. Đodanu je prigovoreno da je tada govorio samo o Hrvatskoj, a da nijednom riječju nije spomenuo Jugoslaviju i „bratstvo i jedinstvo njenih naroda". ${ }^{31}$ On je dakle već tada bio zapažen kao zapaljiv, afektivan govornik koji lako može izazvati kontroverze. Ta njegova aureola s vremenom će samo jačati. U javni prostor znatnije prodrijevši 1968., u 1969. on se gradio kao jedan od glavnih (ekonomskih) programatskih intelektualaca nadolazećega masovnijega gibanja, onoga što će poslije biti označeno Hrvatskim proljećem. Zato je mogao biti udarac njegovoj taštini kad je Šuvar kasnije, u okviru polemike, sebe i Đodana proglasio „politički i znanstveno relativno nejakim pojedincima”. ${ }^{32}$ Pritom treba imati na umu da je Đodan bio devet godina stariji od Šuvara (Šuvar je tada bio u 33., Đodan u 42. godini), pa je i to zapravo bila više polemička iglica za Đodana nego tobožnja Šuvarova skromnost. No međusobna javna polemika zapravo će privući pozornost na obojicu i vinuti ih u medijsku orbitu. Oni su kao mlađi ljudi iskoristili trenutak, zapravo period slobode. Kako smatra Bilandžić: „Ni u jednoj fazi društvenog razvitka Jugoslavije nije bilo tako slobodne i otvorene političke borbe kao potkraj šezdesetih i početkom sedamdesetih godina." ${ }^{33}$

\section{Tijek polemike}

Šime Đodan i Stipe Šuvar 7. siječnja 1969. zajedno su prisustvovali sjednici Komisije za društveno-ekonomske odnose pri Centralnom komitetu Saveza komunista Hrvatske u svojstvu vanjskih stručnjaka, a ujedno članova Saveza komunista. Đodan je tom prilikom održao kraće izlaganje na temu tada nejednakoga regionalnog razvoja u Socijalističkoj Federativnoj Republici Jugoslaviji (SFRJ), odnosa razvijenih i nerazvijenih krajeva, orijentacije jugoslavenske privrede na gubitaške, nepropulzivne grane itd. Šuvar je upozorio na tendencioznost nekih Đodanovih teza i prigovorio mu da previše politizira ekonomska pitanja, no rasprava očito nije iskakala iz uobičajene šprance unutarpartijskoga razgovora, uz upotrebu klasičnoga metajezika, pa je tako Šuvar npr. istaknuo da rješenje ekonomske neravnoteže treba tražiti kroz „integraciju društvenog rada”, a Đodan odgovorio: Ne samo integraciju nego i „optimalnu alokaciju društvenog rada” i „optimalnu integraciju jugoslavenskih gospodarskih struktura u policentrični grupacijski gospodarski model”. ${ }^{34} \mathrm{U}$ Đodanovoj argumentaciji to je, drugim riječima, značilo da više novca treba

30 PETROVIĆ, SUPEK, Jun-lipanj 1968. Dokumenti, 187, 197.

31 Isto, 205-209.

32 ŠUVAR, „Da li je Hrvatska eksploatirana”, 2005.

33 BILANDŽIĆ, Hrvatska moderna povijest, 644.

34 ĐODAN, „Prilog raspravi o regionalnom razvoju u SFRJ”, 252. 
dati zapadnijim krajevima („zapadno od Drine”) jer će ga oni bolje i upotrijebiti. Ta rasprava, kao i mnoge slične na zatvorenim partijskim forumima, vjerojatno bi bila brzo zaboravljena da Đodan u ožujskom broju Matičina časopisa Kolo (koji je iz tiska izašao tek u svibnju) nije odlučio objaviti cjeloviti tekst svojega izlaganja, kao i replike koju je tada dao Šuvaru, da bi na kraju otvorio vrata za moguću polemiku: „ako kolega Šuvar želi sa mnom voditi dijalog, stojim mu na raspolaganju i spreman sam odgovoriti na svaku primjedbu." ${ }^{35}$ Obično je cilj rukovodećih struktura unutar Saveza komunista bio da što manje unutarpartijskih rasprava, često i vrlo žučnih i neortodoksnih, dolazi u javnost. No krajem 60 -ih to se počelo mijenjati. ${ }^{36}$

Iako se Đodan postavio vrlo kritički, pa i revolucionarno-negacijski, prema jugoslavenskoj društvenoj i ekonomskoj stvarnosti, svoje je argumente nastojao postaviti ekonomski neutralno, objektivno, tehnički. Govorio je o tržištu, unutarnjoj ekonomskoj integraciji i uspješnom uključivanju Jugoslavije $\mathrm{u}$,svjetsku podjelu rada”. ${ }^{37}$ Prepreku tome vidio je u birokratskim strukturama (prije svega saveznim) i političkom operiranju kategorijama "razvijenosti” i „nerazvijenosti”, odnosno njihovu poistovjećivanju s nekim republikama, dok je ekonomska stvarnost složenija, pa tako npr. Hrvatska kao „razvijena” republika po nekim ekonomskim kriterijima i sama na svojem teritoriju ima oko $40 \%$ nerazvijenih općina. ${ }^{38}$ Đodan je potrebu pomicanja težišta privredne, pa i financijske snage na zapadni dio Jugoslavije branio argumentima ekonomske logike i zakonitosti. No to nije moglo proći bez utjecaja političke argumentacije. Jugoslavenska ekonomska homogenizacija, kao svojevrsna unutarnja mini globalizacija, kao i kod one prave globalizacije, nije se mogla odvijati bez političke rasprave o njezinim učincima, tj. koliko se takva međunarodna (u jugoslavenskom slučaju međunacionalna) podjela rada odvija u skladu sa zakonom o komparativnim prednostima, a koliko ovisi o odnosima moći.

Zato će i Đodan i Šuvar koristiti selekciju podataka i političkih implikacija koje im odgovaraju, često detaljima rušeći cjelinu slike onoga drugog.

No za Šuvara je te godine polemika s Đodanom bila svojevrsna „utješna" nagrada. On se naime u svibnju, prilikom jednoga idejnog savjetovanja u Gradskom komitetu Saveza komunista Zagreb, najprije namjerio na Petra Šegedina i njegovu priču Izdajnik, također u nastavcima objavljivanoj u Kolu, koja je bila literarna obrada položaja hrvatskoga naroda u socijalističkoj Jugoslaviji. Šegedin je taj položaj oslikao vrlo negativno, praktički je to bila beletristička verzija onoga što je Đodan pisao u obliku ekonomskih traktata, a zajednički nazivnik bila je neravnopravnost i obespravljenost Hrvatske i $\mathrm{Hr}$ vata u SFRJ. Pritom je Šuvar upozorio na to da nacionalisti često prozivaju

35 Isto, 254.

36 JAKIR, „Nemoguća misija i početak kraja? Gospodarske reforme u SFR Jugoslaviji tijekom 1960ih godina”, 93-94.

37 ĐODAN, „Prilog raspravi o regionalnom razvoju u SFRJ”, 246.

38 Isto, 250-251. 
svakoga tko nije Hrvat po njihovoj mjeri: „Zaboravlja se ponekad da u nas ima raznih Hrvata i ja osobno nikome ne dopuštam da tvrdi da je hrvatskiji od mene, ali ne želim ja biti Hrvat kakvi su ovi Hrvati s ovim parolama." 39 No tada još uvijek mlad i relativno nepoznat glavni urednik Naših tema očito nije bio dostojan sparing-partner za uglednoga književnika, akademika i predsjednika Društva književnika Hrvatske. Zato će polemički naoštrenom Šuvaru dobro doći Đodanov „poziv”. Na Đodanovu bačenu rukavicu on će odgovoriti u Našim temama (br. 6, 1969.), a to je u skraćenoj verziji prenosio i Vjesnik (od 12. do 16. lipnja). ${ }^{40}$ Ondje je detektirao tri Đodanove preokupacije: štetnost dosadašnje politike pomaganja nerazvijenima, centralizam (ili kako to Đodan definira: „formalna federacija, što omogućuje vladavinu jugokratske birokracije i dominaciju Beograda”) te posljedično ekonomsko i biološko siromašenje Hrvatske. ${ }^{41}$ Problem koji iz toga slijedi jest da Đodan cjelokupni razvoj Jugoslavije gleda kao odnos među regijama, republikama i narodima, ali ne i ljudima, društvenim klasama - „klasni moment suspendira nacionalnim". Drugo, posljedica toga neizostavno je pretjerivanje, odnosno - nacionalizam, i treće, njegova je argumentacija „jednostrana” i „nepotpuna”, tj. namjerno selektivna. ${ }^{42}$ Naposljetku, Šuvar Đodanovo invociranje „hrvatske nacije” i „hrvatske radničke klase” karakterizira kao „hrvatski malograđanski nacionalizam". ${ }^{43}$ Nakon toga Šuvarova vehementnog, en général odgovora polemika se mogla razviti. U listopadu će uslijediti Đodanov opširni odgovor, opet u Kolu (br. 7, 1969.), na što Šuvar još opširnije odgovara u Našim temama (br. 12, 1969.).

Na optužbe za nacionalizam Đodan uzvraća da je upravo Šuvar taj koji, protiveći se koncepciji otvorene privrede i integracije jugoslavenskoga tržišta, „ruši jedinstvo SFRJ u bazi”, što „ne samo da vodi rasipanju sredstava nego i izgradnji šest zatvorenih privrednih područja u SFRJ, a to je upravo najcrniji nacionalistički koncept ekonomskog razvoja”. „Kako Stipe Šuvar misli očuvati jedinstvo Jugoslavije na ideološkom planu, kad minira jedinstvo u ekonomskom sistemu; kako se može sačuvati krov kad se miniraju temelji." ${ }^{44}$ No u tome je i bio nesporazum. Ono što je Šuvaru temelj (ideologija) Đodanu je krov, i obrnuto, što su Đodanu temelji (ekonomija) Šuvaru je krov, nadogradnja. Zapravo, Đodan se tu nastojao postaviti kao dosljedniji marksist, a Šuvaru je na prvome mjestu bio jugoslavenski specifični kontekst, povijesno i idejno iskustvo.

39 OSTOJIĆ, Javni dnevnik, 186-187.

40 „Društveni razvoj i međunacionalni odnosi u tumačenjima dra Šime Đodana”, Vjesnik (Zagreb), 12. 6. 1969., 9; „O političkom optuživanju nerazvijenih i o argumentima”, Vjesnik, 13. 6. 1969., 5; „Ipak pomoć nerazvijenima, ali...”, Vjesnik, 14. 6. 1969., 6; „O protagonistima i žarištima nacionalističkih inspiracija”, Vjesnik, 15. 6. 1969., 4; „Lažna uzbuna”, Vjesnik, 16. 6. 1969., 4.

41 ŠUVAR, „Društveni razvoj i međunacionalni odnosi u tumačenjima dra Šime Đodana”, 999-1005.

42 Isto, 1014.

43 Isto, 1005.

44 ĐODAN, „Gdje dr Stipe Šuvar 'pronalazi' nacionalizam, a gdje ga ne vidi”, 694. 


\section{Između patriotizma i lokalpatriotizma}

Đodanu će se zgodnom učiniti usporedba koju je upotrijebio novinar Krešimir Džeba kad je obrazac jugoslavenskih krupnih investicija usporedio $s$ američkom intervencijom u Vijetnamu (Vjesnik u srijedu, 18. 4. 1969.): „U mnogo ćemo slučajeva možda biti nalik na Amerikance danas koji su u vijetnamski ratni poligon ulupali toliko para da nikako nemaju smjelosti da ga napuste, iako su već odavna uvidjeli promašenost te investicije." ${ }^{35}$ Potom je Đodan nastavio s nizanjem podataka što govore $u$ prilog osiromašenju $\mathrm{Hr}$ vatske, i to u duljoj vremenskoj perspektivi. Pokazuje pad udjela Hrvatske u jugoslavenskom totalu na svim razinama, pri čemu se može pratiti kontinuitet od 1920-ih do 1960-ih, dakle od prve Jugoslavije do tadašnje: godine 1925. udio Hrvatske (u ondašnjim granicama) u industriji Jugoslavije bio je 33\%, a udio fiksnih fondova industrije i rudarstva Hrvatske u jugoslavenskom totalu od 1946. do 1960. pao je sa $28,6(26,4)$ na $24(22,3)$ posto. U stanovništvu se udio sa $27,3 \%$ smanjio na $21,7 \%$, s najnižim prirodnim prirastom i najvećom tekućom stopom emigracije u SFRJ i jednom od najvećih u svijetu. Udio hrvatskih banaka u bankarskom kapitalu Jugoslavije pao je s preko 50\% na samo 15\%. Nadalje, Socijalistička Republika Hrvatska daje oko 50\% deviznih prihoda Jugoslavije, ali beogradske banke raspolažu sa $81,3 \%$, a zagrebačke samo sa 9,7\% deviza. Đodan te podatke citira pozivajući se na niz drugih autora i ekonomista, počevši od svojega mentora Rudolfa Bićanića (Ekonomska podloga hrvatskog pitanja, 1938.). Takvo navođenje prijeratnih referenci koje se tada sporadično, a potom sve češće pojavljivalo u javnosti posebno će iritirati Vladimira Bakarića, koji je to smatrao prevladanom haesesovštinom, „čistom nacionalističkom tendencom” i zauzimanjem „besprincipjelne opozicije". ${ }^{46}$ No Đodan je svoje teze podupirao i nekim suvremenijim autorima (Ivo Vinski, Ante Čičin-Šain, Gorazd Nikić, Alica Wertheimer-Baletić). ${ }^{47}$ Time je svoje početne pozicije nastojao učiniti samorazumljivima, neupitnima, općim mjestom s kojega treba kretati u bilo kakvo promišljanje tadašnje jugoslavenske i prije svega hrvatske društvene stvarnosti. No neće svi biti impresionirani snagom podataka i brojki koje je iznio.

Primjerice, kad se na Izvršnom komitetu Centralnoga komiteta Saveza komunista Hrvatske (26. svibnja 1969.) raspravljalo o idejnim strujanjima u nekim književnim časopisima, pored Hrvatskoga književnog lista, koji je ocijenjen kao potpuno neprihvatljiv, spomenuti su i neki tekstovi u časopisima Kolo, Kritika, Telegram, Dometi i Dubrovnik, a poimence su prozvani Petar Šegedin (opet), ali i „neki 'gospodarstveni' napisi dra Šime Đodana”. ${ }^{48} \mathrm{Za}$ nje-

45 Isto, 709.

46 HR-HDA-1002-OFVB, kut. 69, „Nekorigirani tekst magnetofonskog snimka razgovora druga dr V. Bakarića sa predstavnicima štampe i RTV dana 5. III. 1969.”, str. 27-28; BILANDŽIĆ, Povijest izbliza, 76-77.

47 ĐODAN, „Gdje dr Stipe Šuvar 'pronalazi' nacionalizam, a gdje ga ne vidi”, 698-699, 702 703, 709-710.

48 „Komunisti i idejna strujanja u književnim časopisima”, Vjesnik, 27. 5. 1969., 2. 
ga će biti rečeno i da „on čak inzistira na opravdanosti investiranja jedino $\mathrm{u}$ krajevima zapadno od Drine” te da u svemu što piše „osjeća se pokušaj ekonomsko-političkog utemeljenja samostalne hrvatske zajednice” ${ }^{49}$ Đodanov će odgovor osim Kola tada htjeti objaviti još samo Borba. On je ponovio tekst svojega izlaganja i istaknuo da nije samo za investicije zapadno od Drine, ali je činjenica da je glavno nerazvijeno područje sada s te strane, a ono je ne samo ekonomski nego, zbog nacionalne izmiješanosti, i vojno-strateški i politički ključno. ${ }^{50} \mathrm{~S}$ druge strane Đodan je već prije odbacio bilo kakve separatističke kvalifikacije i taksativno nabraja za što se on u SFRJ zalaže: perfektna homogenizacija jugoslavenskoga tržišta, jugoslavenska podjela rada, perfektna mobilnost svih faktora proizvodnje (osobito rada i kapitala), optimalno uključivanje svih krajeva SFRJ u razvoj, optimalni razvoj cijele SFRJ, izbor propulzivnih grana i grupacija u kojima imamo bilo prirodne bilo stečene komparativne prednosti za racionalno uklapanje u svjetsku podjelu rada, uklanjanje svih smetnji institucionalne naravi kao što su komunalne, republičke i pokrajinske granice, koje stoje na putu ekonomski opravdanim integracijskim procesima, i poticanje stvaranja jugoslavenskoga grupacijskog modela. ${ }^{51} \mathrm{~S}$ ekonomskoga stajališta ti su stavovi mogli zvučati prirodno, logično, ali su se mogli i drukčije iščitavati. Ne samo kao nešto podložno ekonomskom zdravom razumu nego i voluntarizmu, zahtjevima koji su i politički, koji teže da se asimetrija ekonomske i financijske moći u Jugoslaviji dokine, tj. nagne više na zapadnu stranu, s obećanjem da bi to bilo korisnije i za Jugoslaviju u cjelini.

Uz to što je evocirao "granicu na Drini”, makar samo ekonomsku, Đodan je paralelno sa svojim ekonomskim hrvatovanjem zagovarao i jadransku, primorsku ekonomsku orijentaciju. Tada nisu primijećene sve nijanse njegovih tekstova. Pored toga što je slikao pomalo idiličnu sliku prirodno bogate i gospodarskim potencijalima premrežene (nafta, turizam, brodogradnja itd.) primorske Hrvatske, u Đodanovim analizama mogu se prepoznati i elementi svojevrsne kulturne diskriminacije jer pored obale, otoka, mora, ruda, hidroenergetskoga potencijala, luka, komunikacijske infrastrukture ta se regija, kaže, odlikuje „i - što je najvažnije - s veoma sposobnim i inteligentnim i marljivim stanovništvom, ima veliku gospodarsku perspektivu i s te točke gledišta najatraktivnija je ne samo u SRH, već i u cijeloj SFRJ". ${ }^{2}$ To bi značilo da u ostalim dijelovima Jugoslavije živi manje nadareno stanovništvo te da se već zbog toga ondje manje isplati ulagati ne samo u infrastrukturu nego i u ljude. I zbog nekih drugih razloga te Đodanove „jadranske” teze mogle su izazvati iritaciju u dijelu hrvatskoga i jugoslavenskoga rukovodstva, primjerice ako se prisjetimo historijata napetoga odnosa jednoga prijašnjega velikog zagovornika „jadranske orijentacije” - Vicka Krstulovića s Vladimirom Ba-

49 ĐODAN, „Gdje dr Stipe Šuvar 'pronalazi’ nacionalizam, a gdje ga ne vidi”, 712.

50 ĐODAN, „Investicije zapadno od Drine (O napisima nekih dnevnih listova i obavještavanju javnosti)", 715-716.

${ }^{51}$ Isto, 716.

52 ĐODAN, „Determinante gospodarskog razvoja primorske Hrvatske”, 1. 
karićem, pa i Titom. ${ }^{53}$ Ipak, nema naznaka da bi Bakarić, ili bilo tko drugi, tada poželio ponovno otvarati i tu „lokalnu” frontu. Uostalom, Bakarić je tada spadao među one koji su čitavu problematiku stalno nastojali vraćati na razinu sistemskih rješenja, samoupravljanja kao razrađenoga instrumenta koji će dovesti do slobodnoga raspolaganja dohotkom za proširenu reprodukciju, što bi stvorilo temelje za međunarodnu podjelu rada, unutarnju integraciju, rješavanje međunacionalnih odnosa, pomoć nerazvijenima itd..$^{54}$ No ta se razina u tadašnjoj liberaliziranoj javnoj sferi mogla činiti previše načelna, gotovo sterilna, pa time i manje medijski atraktivna, svakako neprikladna za bilu kakvu mobilizirajuću ulogu, dok su, ponavljamo, nove generacije intelektualaca i političara težile upravo takvoj mobilizaciji. Bitka za samoupravljanje, govorio je Bakarić, vodi se u poduzeću. Da, ali i u javnom prostoru, poručivali su svojim djelovanjem mlađi intelektualno-politički influenseri onoga doba.

Šuvar se za svoj drugi odgovor Đodanu temeljitije pripremio, plasirao svoje (protu)teze i nastojao ih poduprijeti brojkama. Ipak, temeljni nesporazum i dalje će se vrtjeti oko interpretacija raznih podataka, njihove usporedne vrijednosti i političkih implikacija. Ukratko, Šuvar je tumačio da razvoj Jugoslavije uopće nije sporiji od razvoja okolnih zemalja. Bila je to svojevrsna defenzivna pozicija jer se Jugoslavija obično dičila svojim samoupravnim modelom kao nečim što joj omogućava brži razvoj nego ostalima. Nadalje, da je poslijeratna politika bržega razvoja nerazvijenih učvrstila Jugoslaviju, a nije štetila razvijenima, kao i da se u ekonomskom razvitku moraju uzimati u obzir i nacionalni i republički interesi. Dakle, Šuvar razvija svoj eklektični spoj ekonomskoga nacionalizma (republički interesi), solidarnosti (jugoslavenske međuzavisnosti) i socijalističke ideologije. I on i Đodan kombinirali su hrvatsku, jugoslavensku i nadnacionalnu perspektivu, onako kako im je već konveniralo. Tako će Šuvar Đodanovu ideju o ekonomskoj regionalizaciji nazvati „unitarističkom”, pa zato i „hegemonističkom” od strane razvijenih. Također, inzistirat će da ne postoji samo savezna centralizacija nego i republička, pa čak i općinska. ${ }^{55}$

Đodanov grijeh bio je grijeh negacije. Uzeo si je za pravo kritizirati cjelokupni razvoj nakon 1945., opisujući ga za Hrvatsku čak ekonomski gorim od prijeratnoga razdoblja, pozvavši se pritom i na svoj status borca u Narodnooslobodilačkoj borbi. Šuvar na to odgovara ironizirajući njegovo sudjelovanje u partizanima „od jeseni 1944 ” ${ }^{56}$ Da bi poljuljao vjerodostojnost protivnika, Šuvaru je važno osporiti barem poneki podatak, primjerice onaj da Hrvatska ostvaruje 50\% deviznoga prihoda Jugoslavije, ali da beogradske banke raspolažu sa $81,3 \%$, a zagrebačke sa $9,7 \%$ deviznih sredstava. Šuvar međutim, citirajući iste autore kao i Đodan (Ante Čičin-Šain, Gorazd Nikić), nalazi da

${ }^{53}$ MIHALJEVIĆ, „Boro Krstulović: Djedovi sukobi s Brozom i Bakarićem”, 80-84.

54 HR-HDA-1002-OFVB, kut. 69, „Razgovor dr. V. Bakarića sa dopisnicima RTV i Vjesnika u inozemstvu /stenogr/, 18. 2. 1969.", str. 27.

55 ŠUVAR, „Da li je Hrvatska eksploatirana”, 2021.

56 Isto, 2022. 
Hrvatska daje $38,4 \%$, a troši 36,2\% deviznih prihoda Jugoslavije. ${ }^{57}$ Znakovita je i Šuvarova (sociološka) definicija jugoslavenske federacije, koja nije klasična federacija, već „ništa drugo nego društveni odnos koji od revolucije naovamo ostvaruje i izražava nacionalnu slobodu naših naroda u uvjetima njihove uzajamnosti i povezanosti socijalističkim produkcionim odnosima". ${ }^{58}$ Bilo je to samoupravno shvaćanje jugoslavenstva kao međudjelovanja povijesne uzajamnosti, socijalističke ideologije i društva. Sama država i državni suverenitet u toj su jednadžbi sekundarni, više nužni okvir u kojem se reproduciraju ova tri faktora. No preko tako relacijski shvaćene federacije, kao „društvenoga odnosa", širom su otvarana vrata njezinim mijenama. To je ustvari bio poziv na stalno perpetuiranje promjene, zapravo na trajno tinjajuću nestabilnost. Šuvar i Đodan slažu se da centralizam ne pogoduje slobodnom razvoju takva društvenoga odnosa, no dok je Šuvar centralizam vezivao uz sistem, Đodan ga je spajao s „najbrojnijom nacijom”, tj. Srbima. ${ }^{59}$

Zato Šuvar povlači demarkacijsku liniju između njih, bez obzira na to što su obojica borci protiv centralizma, motivi su im različiti. Različita je i njihova definicija radničke klase. Za Đodana moderno shvaćenu radničku klasu čine svi oni „koji sudjeluju u stvaranju narodnog dohotka, a tu ubrajamo i tehničku i ostalu inteligenciju koja je zaposlena u gospodarskoj aktivnosti društva”. ${ }^{60}$ Šuvar pristaje uz bitno užu definiciju po kojoj „radničku klasu čine neposredni proizvođači u oblasti materijalne proizvodnje, dok su svi ostali pripadnici društva u odnosu na njih više ili manje privilegirana 'kontraklasa"' ${ }^{11} \mathrm{O}$ tim se pitanjima inače tih godina dosta raspravljalo, i u okviru novih strujanja u marksističkoj misli, posebno s obzirom na potencijal sve veće konvergencije radničke i srednje klase. ${ }^{62}$ No u ovom slučaju nije teško objasniti zašto je Šuvar bio bliži užoj, a Đodan široj definiciji radničke klase. Naime, pri svakom širenju definicije radničke klase raste rizik njezina poopćavanja, pa posljedično i utapanja u nacionalnu esenciju. Inzistiranjem na klasnim razlikama u proizvodnom procesu kod radničke klase zadržava se osjećaj njezine avangardne uloge. Ali za njih je to tada ionako bilo ponajviše teorijsko pitanje. Glavnina spora ipak se odvijala na ravni ekonomske teritorijalizacije. Šuvar upozorava na nedostatak egzaktnih podataka i istraživanja, zbog čega se ne može tako lako odrediti koje su to loše i neisplative investicije od kojih će „biti male ekonomske koristi”. To upozorenje bilo je izlišno, za Đodana je taj tip argumentacije ionako uvijek bio više emocionalne, afektivne prirode, onaj koji se kupi s ulice, iz mentaliteta, a ne iz statistika. Naposljetku, Šuvar je još prije priznao da primjerice izgradnja elektrane Đerdap, pruge Beograd - Bar

57 Isto, 2044.

58 Isto, 2022-2023.

59 ĐODAN, „Prilog razmatranju predloženih izmjena Ustava SFRJ”, 472.

60 ĐODAN, „Problemi razdiobe u našem društvu”, 196.

61 ŠUVAR, „Da li je Hrvatska eksploatirana”, 2030.

62 URRY, „Towards a Structural Theory of the Middle Class”, 176, 181; POULANTZAS, Classes in Contemporary Capitalism; HORVAT, Ogled o jugoslavenskom društvu, 123. Branko Horvat odbacivao je podjelu na proizvodni i neproizvodni rad kao teorijski neutemeljenu. 
i neki drugi veliki projekti u „dunavskoj regiji” trenutačno uistinu ne djeluju kao optimalne investicije, ali za ocjenu o njihovoj dugoročnoj neisplativosti potrebna su detaljnija istraživanja itd. ${ }^{63}$ Šuvar donekle priznaje i tezu o demografskom („biološkom”) siromašenju, o čemu je, kaže, pisao i više od Đodana, ali opet ističe da isti trend doživljavaju i Vojvodina, uža Srbija i Slovenija, kao uostalom i cijela Europa i Sovjetski Savez. Zato to ne treba koristiti za napad i optužbu prema drugim narodima. Demografska kretanja, suprotno od onoga kako bi „nacionalisti” htjeli, neovisna su o ekonomskim, političkim i kulturnim odnosima među jugoslavenskim narodima i republikama. ${ }^{64}$

No, zaključuje Šuvar, konstanta „hrvatskog malograđanskog nacionalizma" već više od stoljeća jest nepovjerenje u svaku državnu i drugu vezu jugoslavenskih naroda. Za Šuvara je to nacionalizam koji inzistira na razgraničenjima. Pomalo i sam u duhu nacionalnoga patosa, on zaključuje da je taj nacionalizam

„[...] uvijek bio bacil koji je nagrizao snagu hrvatskog naroda, razoružavao ga u prekretničkim okolnostima, zamračivao mu perspektive onda kada su se one otvarale, gurao ga na stranputice povijesnih kretanja, konzervirao oblike njegove nacionalne svijesti, djelovao uvijek i u svim okolnostima u retrogradnom smjeru: umišljajući da je spasilac bio i ostao štetočina”. ${ }^{65}$

U suvremenom kontekstu značajka toga nacionalizma jest shvaćanje da je nova Jugoslavija tek malčice popravljena stara Jugoslavija i da ni u njoj hrvatski narod nije svoj na svome. ${ }^{66}$ Ipak, stvarnost je bila složenija od onoga kako ju je Šuvar nastojao definirati. Tzv. novi hrvatski nacionalizam tih godina, oličen u mladoj generaciji komunista i ne-komunista, nastojao je sebi dodati i novu kvalitetu, pokazati svoju modernizacijsku ulogu, dokazati da nacija (a ne samo radnička klasa) može biti nositelj napretka.

\section{Nacija je (ne)prevaziđena?}

Istovremeno će hrvatski komunist unitarističke provenijencije Miloš Žanko u Beogradu govoriti: „Naime, naučno-tehnička revolucija i nova društvena podjela rada, nova društvena podjela rada koja izvire iz novih savremenih proizvodnih snaga dolazi do toga da nacija više nije prirodni nosilac razvijanja ekonomskih procesa." ${ }^{67}$ No bilo je to tada već manjinsko mišljenje. Ne samo da se naciju više nije isključivalo iz ekonomske jednadžbe, nego se ni

63 ŠUVAR, „Društveni razvoj i međunacionalni odnosi u tumačenjima dra Šime Đodana”, 1007.

64 ŠUVAR, „Da li je Hrvatska eksploatirana”, 2057-2058.

65 Isto, 2063.

66 Isto, 2064.

67 SR-AJ-507-SKJ, XXIIIC, kut. 3/10, Radne grupe komisije PSKJ za razvoj društveno-političkih zajednica i medjunacionalne odnose: Sednica radne grupe 26. 9. 1969., str. 3/1-3/2. 
ekonomiju nije moglo svoditi samo na proizvodnju, tehnologiju upravljanja resursima, klasne odnose, već ju je trebalo promišljati u suodnosu s identitetom, kulturom itd.

Šuvar je tu simbiozu, među ostalim i kroz Đodanovu aktivnost, pratio još otprije, kad je npr. u studenom 1968. na plenumu Društva književnika Hrvatske Đodan održao uvodno izlaganje o „Razdiobi narodnog dohotka u SFRJ i financiranju kulture", gdje je iznio dosta ekonomskih podataka i brojčanih pokazatelja (Telegram, 22. 11. 1968.), što je ostavilo jak dojam na prisutne književnike. ${ }^{68}$ Svakako, bilo je znakovito da se na skupovima jednoga društva književnika živo raspravlja i o ekonomskim pitanjima. Bio je to pokazatelj da će $u$ idućem periodu sve tanjom bivati granica između brojki i slova, ideja i podataka, statistike i beletristike i da ne može vrijediti ona kruta i pojednostavnjena dihotomija koju je i Šuvar nastojao održati, a po kojoj je jednostavno „[n] acionalizam [...] emocionalna a ne racionalna reakcija”. ${ }^{69}$

Sličan primjer bila je i rasprava o Dubrovačkim ljetnim igrama koju je Matica hrvatska organizirala u ljeto 1968., u kojoj je pored kulturnih radnika, pisaca i kritičara (Branimir Donat, Tomislav Ladan, Trpimir Macan, Igor Mandić, Luko Paljetak...) sudjelovao i Šime Đodan kao jedini ekonomist. On je i tu priliku iskoristio da ponovi svoje ekonomske teze o iskorištenosti Hrvatske, ali i da istakne da bi na manifestaciji kao što su Dubrovačke ljetne igre centralni dio programa trebao pripasti hrvatskoj kulturi, pa tek onda kulturama ostalih naroda SFRJ. ${ }^{70}$ I to je bio jedan od simptoma trajne „razgraničavajuće” osobnosti hrvatskoga nacionalizma na svim poljima o kojoj je govorio Šuvar. Nasuprot tome, on je sve želio transcendirati ovakvim zaključkom:

„Kada su se borili za ukidanje državnog kapitala, i kada se još zalažu za optimalne oblike disponiranja njegovim preostalim dijelom, kada se bore za deetatizaciju bankarskog sistema i ukidanje određenih nasljeđenih monopola $\mathrm{u}$ vanjskoj trgovini, za mnogo veće pravo onih koji devize izvozom ostvaruju da njima raspolažu, kad se zalažu za putove samoupravne integracije, a protiv novih monopolskih struktura privređivanja, pa i kada se zalažu za preispitivanje politike razvoja nedovoljno razvijenih područja, jednom riječju, kada se bore za konsekventno provođenje reforme i za proizvođačko ovladavanje društvenom reprodukcijom, komunisti i radni ljudi Hrvatske znaju da se ne bore za neke svoje posebne interese, koji bi išli na uštrb interesa radnih ljudi svih ostalih ili bilo koje druge naše nacije i republike. Oni znaju da se radi o bitno zajedničkim interesima i borbi." ${ }^{\text {71 }}$

No pored egzaltiranoga tona, ovakva tipično ideološka retorička strategija na drugi pogled može se čitati i kao naličje nacionalno-esencijalističke vizije,

\footnotetext{
68 ŠUVAR, „Društveni razvoj i međunacionalni odnosi u tumačenjima dra Šime Đodana”, 1015.

69 Isto.

70 ĐODAN, „Ljetne igre - gospodarske odrednice - povijest”, 30 .

71 ŠUVAR, „Društveni razvoj i međunacionalni odnosi u tumačenjima dra Šime Đodana”, 1019.
} 
one po kojoj je moguće da kad jedna nacija ostvari svoje ciljeve i svi njezini pripadnici pojedinačno žive u blagostanju, a u ovom slučaju da je moguće izboriti se za sve, pa i one nacionalne interese, a da istovremeno to ne bude na štetu bilo koga drugog. Šuvar dakle završava s emocionalnim, političkim i ideološkim argumentom solidarnosti i uzajamnosti. On je kritizirajući emocionalne nasuprot racionalnim argumentima i sam završio u polju afektivnoga.

Šuvar Đodana poslije eksplicitno proglašava unutarnjim neprijateljem $u$ Savezu komunista i pita se zašto on „ne izvlači radikalnu konzekvenciju iz svojih pogleda u smislu odlučnog distanciranja od one političke organizirane snage koja snosi odgovornost za današnji položaj i razvitak Hrvatske". ${ }^{72}$ Drugim riječima, zašto se ne proglasi otvorenim protivnikom Saveza komunista? U tome je tada bio sličnih stavova kao i Miloš Žanko, za koga je Đodan također samo „nažalost član Saveza komunista”. ${ }^{73}$

No dok se u Zagrebu i Beogradu, po partijskim forumima i u tisku, rutinski kritiziralo hrvatski nacionalizam i nacionaliste, a neki poput Žanka, pa djelomično i Šuvara, toj kritici nastojali dati novi zamah, sveobuhvatnost i kvalitetu, istovremeno su iza kulisa stvari mogle izgledati drukčije. Tako će, prema tvrdnjama Dušana Bilandžića, baš negdje u kolovozu 1969. članu Saveznoga izvršnog vijeća i ekonomistu Rikardu Štajneru Josip Broz Tito iza zatvorenih vrata reći „da je Hrvatska politički jedina svijetla točka u Jugoslaviji. Treba spriječiti da Genex ulazi u naftnu industriju: 'Gurajte vi vašu politiku, ne obazirite se na mene"' ${ }^{74}$ Očito, bez obzira na sve, Tito se tih dana ipak postavio kao diskretni, ali odlučni gromobran novoga Centralnoga komiteta Saveza komunista Hrvatske na čelu sa Savkom Dabčević-Kučar. Miloš Žanko uskoro će u listu Borba (od 17. do 21. studenog 1969.) početi sa serijom svojih članaka na temu nacionalizma u politici i kulturi pod naslovom „U toj (nacionalističkoj) ludosti - ima sistema". Tu će imenovati mnoge aktere, proziva gotovo sve istaknutije članove Upravnoga odbora Matice hrvatske, a Šimi Đodanu posvećuje čak i posebno poglavlje. Žanko je tada svojim istupima velik dio hrvatskih javnih glasila, intelektualaca, pa i političkih struktura trpao u isti (nacionalistički) koš te nastojao „stvoriti uvjerenje da u Hrvatskoj svi spavaju, dok samo on bdije” ${ }^{75}$ Svojom isključivošću uspio je iziritirati čak i neke koji su se i sami medijski pozicionirali kao zajedljivi kritičari hrvatskoga nacionalizma. ${ }^{76}$ Tako je otvorio sve bokove za obračun koji će s njim, kao

72 ŠUVAR, „Da li je Hrvatska eksploatirana”, 2003.

73 SR-AJ-507-SKJ, XXIIIC, kut. 3/10, Radne grupe komisije PSKJ za razvoj društveno-političkih zajednica i medjunacionalne odnose: Sednica radne grupe 26. 9. 1969., str. 1/33.

74 BILANDŽIĆ, Povijest izbliza, 80.

75 MANDIĆ, Notes: VUS 1968-1972. [pretisak teksta od 3. prosinca 1969. „Kesten-pire Miloša Žanka"], 256.

76 „Bez ikakve kritičke razložnosti on je ustvrdio da su raznorodne pojave i mišljenja povezani žicom anti-socijalizma, što je virtuozna konstrukcija - bez ikakvih dokaza. Ovdje ne treba 'braniti' ni Maticu hrvatsku, ni autore koje je Miloš Žanko spominjao, ni 'Telegram', ni 'Kritiku', ni 'Kolo', a još manje 'HKL', 'Glas koncila', 'Marulića' itd. U cijeloj toj hrpi koju je nagomilalo bespoštedno i grubo Žankovo pero zacijelo ima kukolja, a to je, mnogo prije nego 
unitaristom, uslijediti na 10. sjednici Centralnoga komiteta Saveza komunista Hrvatske u siječnju 1970. godine. S druge strane, novi vrh Saveza komunista Hrvatske tada je odlučio ublažiti odnos prema Matici hrvatskoj. Tih su dana na jednom sastanku u Centralnom komitetu Saveza komunista Hrvatske s komunistima iz Matice kao negativna pojava izrijekom izdvojeni samo „Autsajderski fragmenti” Vlade Gotovca, objavljeni u osmom broju časopisa Kritika. ${ }^{77}$ Drugim riječima, za Šimu Đodana i većinu njegovih bliskomišljenika godina 1969. završavala je bolje nego što je počela, s više razloga za optimizam i više autonomije koje im je ostavljalo novo hrvatsko političko vodstvo. Iako je u svojim opsežnim odgovorima Šuvar uspio relativizirati, pa i osporiti, dobar dio Đodanovih teza, ipak je javno-politički kontekst u Hrvatskoj tih dana više pulsirao i korespondirao s Đodanovim porukama. ${ }^{78} \mathrm{Za}$ Hrvatsku se u Jugoslaviji pošto-poto htjelo i tražilo više. No u javnosti, pa i onoj intelektualnoj, koliko god se prostor slobode širio, ipak nije bilo dovoljno volje za otkrivanje i bavljenje svim slojevima koje je ta polemika, nadilazeći njezine glavne ili sporedne sudionike, nosila. Čitav niz tema bio je prekompleksan i ne previše pogodan za (zlo)upotrebu u gradnji masovne politike prema kojoj se tada smjeralo.

\section{Bit polemike - sraz i suodnos (ekonomskih) nacionalizama i globalizama}

Odnos nacionalizma i međunarodne ekonomske integracije (unutar Jugoslavije i Jugoslavije sa svijetom), odnos ekonomije i kulture, emocionalnih i racionalnih argumenata u političkoj i ekonomskoj sferi, nacionalizma i demografije, modernizacije i nacionalne emancipacije, međudjelovanja procesa $\mathrm{u}$ istočnom, socijalističkom lageru i na Zapadu te njihove posljedice na Jugoslaviju itd. neke su od prizmi kroz koje se mogla sagledati i dalje razvijati spomenuta polemika. To su bile velike, prijelomne teme unutarjugoslavenske, ali i međunarodne, svjetske konstelacije. Premda su mnogi problemi i protus-

što se Žanko sjetio, utvrđeno i pokazano na razini naših političkih i društvenih institucija i, napokon, samouvjereno govoreći, i na ovom skromnom mjestu. Ali, kao što ima kukolja - ima i dobrih namjera, poštenih ljudi, predratnih komunista, ljudi koji su prošli kroz fašističke i ustaške logore, članova SK, dobrih i izvrsnih stručnjaka, sjajnih pisaca, marljivih znanstvenih radnika. Svi oni nisu oličeni istom bojom kao što se čini nekom daltonistu." Cit. prema: MANDIĆ, Notes: VUS 1968-1972., 259.

77 Borba (Beograd), 18. 11. 1969., 7.

78 I Šuvar će godinu dana nakon ove polemike malo promijeniti naglaske. Krajem 1970., u nikad objavljenom intervjuu za beogradski tjednik NIN, na pitanje o opasnosti jačanja republičkoga etatizma reći će: „Ali htio bih upozoriti da nas danas mnogi plaše republičkim etatizmom, jer žale što tako brzo propada savezni! [...] Moram reći da proizvođači mogu lakše izići na kraj s nacionalnom nego nadnacionalnom državom, vlašću i birokracijom. Ja se, recimo, više plašim eventualne osobne vlasti jednog čovjeka nego jačanja nacionalnih državnosti. Bojim se vlasti koja bi govorila: pustite naciju, slušajte mene!” Cit. prema: ŠUVAR, Socijalizam i nacije, sv. 2, 108. 
lovlja jugoslavenskoga društva mnogo ranije detektirani i adresirani na zatvorenim partijskim forumima nego u najširoj javnosti, oni su rijetko bivali do kraja konkretizirani. U jednom internom partijskom materijalu iz 1966. bit će dobro prepoznato da je socijalizam, mimo teorije, u praksi često zanemarivao nacionalno pitanje kao ekonomsko, a pristupao mu samo kao političkom problemu. ${ }^{79}$ No bez obzira na takve dijagnoze, postojao je trajni strah od posljedica koje produbljivanje ekonomskih problema može imati za međunacionalne odnose. Nakon VIII. kongresa Saveza komunista Jugoslavije (1964.), uoči privredne reforme (1965.) neke od tih strahova nastojalo se ukrotiti. Čak i najviši partijski funkcionari znali su iznenaditi otvorenošću svojih stavova. Primjerice, Edvard Kardelj govorio je da je pogreška kad na međunacionalne odnose u Jugoslaviji „gledamo kao na nešto izuzetno, kao da su odnosi izmedju jugoslavenskih naroda drugačiji nego što su odnosi izmedju nekih drugih naroda. Ništa u tim odnosima nema izuzetnog, osim da nas je historijska sudbina spojila, da smo u etničkom pogledu bliski itd." ${ }^{80}$ Je li to značilo da je sukob interesa među tim narodima neizbježan? Brza industrijalizacija i ekonomski rast 50-ih i 60-ih godina, uvođenje tzv. tržišnoga socijalizma imalo je i svoje naličje, rast nezaposlenosti, produbljivanje razlika između razvijenih i nerazvijenih (sjever - jug), inflaciju, rast vanjskoga duga itd. Politički i ekonomski problemi isprepleli su se više nego ikad. U drugoj polovini 60 -ih cilj je bio osnažiti suverenitet republika, ali istovremeno uspostaviti ekonomski i društveni sistem koji bi nadilazio teritorijalne i političke granice te djelovao integrativno. Jugoslavija je tražila put i model svoje unutarnje globalizacije da bi se bolje pripremila za izlazak u svjetski sistem. Đodan i neki drugi u tom su procesu naprosto tražili bolji početni položaj za Hrvatsku. To je prirodno dovodilo do odnosa konkurencije. Jugoslavenski komunisti bili su toga svjesni i uvijek su se u takvim pripetavanjima osjećali nelagodno jer su znali da je na kocki mnogo više od ekonomskih interesa. Možda je najbolji primjer takve oprezne političke ekvilibristike bio upravo Vladimir Bakarić. On je još u drugoj polovini 1968. javno prozivao beogradske banke i reeksportna poduzeća u kojima su se koncentrirala sva financijska sredstva koja su se nekad nalazila u saveznim fondovima. ${ }^{81} \mathrm{U}$ zatvorenom krugu znao je biti mnogo radikalniji, govorio je da je ponašanje tih privrednih subjekata „čista pljačka Jugoslavije... i to beogradska pljačka”. ${ }^{82}$ Rasprava o financiranju velikih jugoslavenskih infrastrukturnih projekata u javnost je prodrla i ostala upamćena kao „debata o bilancama federacije”. Bakarić i ostali hrvatski predstavnici ipak su se nevoljko uključili u tu raspravu, upravo zbog straha za međunacionalne odnose. ${ }^{83}$ No koliko god su se oni trudili složena ekonomska pitanja maknuti iz javne

\footnotetext{
79 „Međunacionalni ekonomski odnosi”, CK SKJ [interni materijal], srpanj 1966., 6.

80 BILANDŽIĆ, „Slovenija i ostala Jugoslavija - ideja Borisa Kidriča i Edvarda Kardelja”, 376.

${ }^{81}$ MUJADŽEVIĆ, „Stavovi Vladimira Bakarića o centralističkoj opoziciji (1966-1969)”, 50 .

82 Isto.

83 Isto, 52.
} 
rasprave i sistem popravljati iza zatvorenih vrata, toliko zainteresirana javnost više nije htjela zatvoriti te teme.

Stoga su na test stavljene pozicije upravo onih starijih, ali i liberalnijih jugoslavenskih komunista poput Edvarda Kardelja i Vladimira Bakarića, koji su pak, da bi sačuvali manevarski prostor svojega metodološkog liberalizma, na protivnike bili spremni udariti i vrlo neliberalnim sredstvima. To ih je u osnovi činilo okosnicama konzervativnoga shvaćanja. Slobodu i povjerenje koje su davali sebi nisu u jednakoj mjeri bili spremni dijeliti s drugima. Liberalizacija je bila u redu dok je dolazila odozgo, a kad je počela nadilaziti sistem, postala je prijetnja i problem. ${ }^{84}$

Tako se i rasprava Šuvar - Đodan može promatrati samo kao odjek rasprave u partijskom vrhu Jugoslavije, ali rasprave koja je u novom, javnom kontekstu i s novim akterima zadobila i novu kvalitetu i time postala opasnijom. Pokazalo se da je ekonomska dimenzija nacionalizma neodvojiva od specifičnoga nacionalnog diskursa, dakle da ju se ne može zaobići generalnom raspravom o ekonomskoj teoriji i praksi, niti ekonomskoga nacionalizma ima izvan zasebnoga nacionalnog, političkog i kulturnog sistema.${ }^{85}$ Što znači da se ekonomski nacionalizam može usko vezati i uz pitanje suvereniteta. ${ }^{86}$ No čak i kad se državu teži potisnuti iz ekonomskih poslova, što je bio ideal liberalnoga, ali i samoupravnoga ekonomskog sistema, ipak nacionalni ekonomski interesi opstaju i ograničavaju krajnju depolitizaciju tržišta. ${ }^{87}$

Kako ekonomska globalizacija nema nikakva učinka na dokidanje nacije, pa ni države, tako ni unutarnja jugoslavenska ekonomska integracija nije mogla dokinuti nacionalne posebnosti. Ekonomski nacionalizam nije isto što i protekcionizam i nije ispravno naprosto ga suprotstaviti globalizaciji. Dapače, on može biti i za više otvorenoga i slobodnoga tržišta. ${ }^{88}$ Ekonomsko zatvaranje i otvaranje za njega su strategije ostvarenja interesa, a ne stvar principa. Jugoslavenski socijalistički okvir iz sebe je isključivao nacionalizam kao pokret i ideologiju, s druge strane povremeno se služio i paktirao je s diskurzivnim nacionalizmom, ali je možda najviše perpetuirao tzv. svakodnevni nacionalizam. ${ }^{89}$ Naime, osjećaj nacionalne pripadnosti može biti osnažen već i reprezentacijom nacionalne ekonomije kao zasebnoga područja, npr. ekonomske statistike konstantno reproduciraju ideju nacionalnoga ekonomskog prosto-

\footnotetext{
84 Za pitanje karaktera i prikladnoga naziva Kardeljeve i Bakarićeve frakcije u Savezu komunista Jugoslavije te o pojmu i praksi „liberalizacije” jugoslavenskoga društva 60-ih godina vidi: RUSINOW, Yugoslav Experiment 1948-1974, 158-159; LAMPE, Yugoslavia as History, 289-291; RAMET, The Three Yugoslavias, 209-212, 218-219; MIHALJEVIĆ, „Liberalizacija 1960-ih godina - podloga Hrvatskog proljeća”, 273.

85 PICKEL, „Explaining, and Explaining with, Economic Nationalism”, 116-117.

86 HELLEINER, PICKEL, Economic Nationalism in a Globalizing World, 225.

87 MAYALL, Nationalism and International Society, 93-96.

88 FETZER, „Nationalism and Economy”, 964; PRYKE, „Economic Nationalism: Theory, History and Prospects", 283-284.

89 BILLIG, Banal Nationalism; HAMMET, „From banal to everyday nationalism: narrations of nationhood".
} 
ra. ${ }^{90} \mathrm{Kad}$ su se Đodan i Šuvar u okviru svoje polemike pozivali primjerice na podatke Republičkoga zavoda za statistiku, već je postojanje takvih jasno republički, pa onda i nacionalno određenih podataka promoviralo i određenu nacionalno-ekonomsku logiku. Potom se, doduše, Šuvar upinjao te podatke, koji su već po definiciji nacionalno impostirani, nacionalno neutralizirati, interpretirati ih tako da budu nacionalni, ali ne i nacionalistički. No mnogo je jednostavnije takav samorazumljivi okvir iskoristiti, a to je djelomično činio Đodan, za imaginiranje i konstruiranje nacionalno-ekonomskih kultura. Tako se ideja svakodnevne nacionalne jedinstvenosti može graditi i preko poistovjećivanja nacije s određenim ekonomskim vrijednostima, praksama, djelatnostima, institucijama. ${ }^{11}$ Zato je i postojala bojazan da će se Beograd, tj. Srbija, poistovjetiti s reeksporterima, bankama, financijskim kapitalom, ali se s druge strane inzistiralo na turizmu, brodogradnji, pomorstvu kao dijelovima hrvatskoga (ekonomskog) identiteta. Bilo je to neumoljivo djelovanje tzv. nacionalizacijskoga mehanizma koji je usisavao sve u sebe. Taj mehanizam podjednako može djelovati i u uvjetima stabilnosti i integracije i uvjetima promjene i dezintegracije. U takvim uvjetima i globalizacija postaje dio nacionalizacije jer dominantni akteri, tj. države, nastoje metode globalne integracije prilagoditi sebi. ${ }^{92}$ Takvih tendencija bilo je i unutar Jugoslavije. Ako su hrvatski nacionalisti poput Đodana i bili za svojevrsnu unutarnju jugoslavensku integraciju, nije im bilo svejedno pod kojim će se uvjetima ona odvijati. Zašto Hrvatska umjesto da u takvoj integraciji stagnira ne bi mogla biti i ekonomski hegemon? On je uostalom i otvoreno pisao da bi u sklopu optimalnoga modela ekonomske politike za koju se zalagao, svojevrsne kombinacije organskoga (nasuprot državnom) planiranja i tržišta, uz čuvanje visoke zaposlenosti, "SRH imala [...] jednu od vodećih uloga”. 93 Taj „hegemonizam” bazirao bi se na hrvatskim komparativnim prednostima, prijašnjoj industrijskoj tradiciji, pogodnom tlu za daljnji razvoj industrije (maritimne, aluminijske, naftne, kemijske, drvne i dr.), iskustvu tržišta, školovanoj radnoj snazi, koncentraciji stručnjaka itd. Naravno, to ne bi isključilo element solidarnosti prema ostalima u SFRJ.$^{94} \mathrm{U}$ idealnoj projekciji bio bi to neki oblik kompetitivne, poticajne solidarnosti. No dok su i Šuvar i Đodan javno govorili o nekakvoj harmoniji interesa, optimalnom ili komplementarnom razvoju u kojem se svi sretno i uspješno razvijaju, Vladimir Bakarić iza kulisa je govorio o ekonomskoj zakonitosti i slobodnom formiranju cijena kad je normalno da „uvijek neko nekoga pljačka". ${ }^{95}$ Mislio je pritom na odnose neravnopravnosti među poduzećima,

90 MITCHELL, „Fixing the Economy”, 89; TOOZE, „Imagining National Economies: National and International Economics Statistics 1900-1950”, 212-228.

91 CONRAD, Globalisierung und Nation im Deutschen Kaiserreich.

92 WEISS, „Introduction: bringing domestic institutions back in”, 4, 15-19.

93 ĐODAN, „Gospodarska reforma i izbor optimalnog modela rasta”, 307.

94 Isto.

95 HR-HDA-1002-OFVB, kut. 69, „Razgovor dr. V. Bakarića sa dopisnicima RTV i Vjesnika u inozemstvu /stenogr/, 18. 2. 1969.”, str. 34. 
ali to se neizbježno prenosilo i na teren republika. ${ }^{96}$ Nadalje, odnos integracije i dezintegracije privrednih subjekata postavljao je tako da

„[s]vaka integracija koja nije pravljena da podigne produktivnost rada - bolje da je nema. I suviše često su one pravljene za to da se spasi netko tko je nerentabilan. Treba ih pustiti, prije će naći putove rješenja budu li sami plivali u hladnoj vodi, nego ako ih budemo stalno izvlačili i topili onog drugog. Dosad je uglavnom bilo tako; nerentabilni se prikači rentabilnom pa se onda utopi onaj koji je vrijedniji. Slično je kada se prisilom oročavaju obrtna sredstva za to da bi se negdje investiralo. To je provodjenje stare politike investicija administrativnim putem". ${ }^{97}$

I ovdje je Bakarić govorio o poduzećima, ali implicitno i o republikama. No bilo je jasno da put političke decentralizacije s jedne, a ekonomske integracije s druge strane teško može biti idealno komplementaran i pravocrtan. Mnogi strahovi, i od unutarnjega i od vanjskoga povezivanja, održavani su sa samoga vrha. Tito je vjerovao da bi prevelika ekonomska integracija sa zemljama zapadne Europe dovela Jugoslaviju u inferiorni položaj, gdje bi ona postala tek sirovinski privjesak i tržište na koje bi Zapad izvozio svoje proizvode. Isto tako postojala je bojazan da bi veća ekonomska suradnja sa Zapadom dovela do pokušaja mijenjanja Jugoslavije iznutra. ${ }^{98}$ Bakarić je govorio i o velikom strahu pred tržištem: „Dio tog problema nastao je jer nismo definirali što znači tržište, pa je iz toga nastao opći strah da tom tržištu ne idemo brže. Jer, to[g] slobodnog socijalističkog tržišta, naglašavam socijalističkog, kod nas u stvari nema." ${ }^{99}$ Ključni problem privredne reforme i bio je upravo kako spojiti tržišnu privredu s jednopartijskim sistemom, samoupravljanjem, društvenom svojinom i decentraliziranom federacijom. Ta reforma imala je svoje implikacije i na nacionalno pitanje, tj. pitanje različitih brzina kojima se razvijaju republike u Jugoslaviji. I početkom i krajem 60 -ih godina problemi su bili isti, ali u međuvremenu su smjena generacija, smjena Aleksandra Rankovića, nusprodukti privredne reforme iz 1965., poticaji koji su dolazili izvana (npr. Praško proljeće), kao i globalna ekonomska uzlazna putanja dali vjetar u krila smjelijim reformskim nastojanjima. U svakom slučaju, generalni jugoslavenski pravac obično je bio taj da decentralizacija na gospodarskom planu nastupa prije političke decentralizacije. ${ }^{100}$

${ }_{96}$ Kako je jedan češki ekonomist ironično opisao nužnost upotrebe kapitalističkih cijena za socijalističku trgovinu: „Kada kucne čas svjetske revolucije, morat ćemo sačuvati barem jednu kapitalističku zemlju. Inače nećemo znati po kojim cijenama da trgujemo." Cit. prema: NOVE, The Economics of Feasible Socialism, 109.

97 HR-HDA-1002-OFVB, kut. 69, „Razgovor dr. V. Bakarića sa dopisnicima RTV i Vjesnika u inozemstvu /stenogr/, 18. 2. 1969.", str. 40-41.

98 BEKIĆ, Jugoslavija u hladnom ratu, 655-656.

99 HR-HDA-1002-OFVB, kut. 69, „Diskusija dr. V. Bakarića na III sjednici CK SKH, 21. 2. 1969.", str. 5.

100 JAKIR, „Nemoguća misija i početak kraja? Gospodarske reforme u SFR Jugoslaviji tijekom 1960ih godina", 97; RAMET, Nationalism and Federalism in Yugoslavia, 71. 
Đodan i Šuvar trudili su se u svojim pisanjima pokazati da misle o Jugoslaviji kao cjelini, Đodan više ekonomski, a Šuvar ideološki. Ipak, ni ta polemika, bez obzira na to što je slobodno otvorila mnoga pitanja, nije mogla razriješiti stare dileme. Intelektualne rasprave toga tipa rijetko, ili gotovo nikad, završavaju tako što jedna strana uvjeri drugu. Obično svatko ostane pri svome, sučeljavanje se nastavlja na drugome mjestu, u drugom obliku, nekad i s drugim akterima. Arbitri često dolaze izvana, iz sfere političkoga. No u borbi ideja nema konačnih presuda. Ideja kojoj je ukinut status legitimne ili službene povlači se na teren neformalnoga utjecaja i čeka svoj novi trenutak. Stoga će i taj sraz mišljenja naposljetku samo ojačati trajno (jugoslavensko) pitanje: „Tko koga eksploatira?” Upravo je to pitanje bilo poligon na kojem su se kalile nove političke (i intelektualne) elite. ${ }^{101}$

Ipak, na drugoj strani polemika Šuvara i Đodana može poslužiti kao dobar primjer i podsjetnik na promišljanje prakse (više nego pojma) globalizacije pod socijalizmom, posebno u njegovu reformskom razdoblju 60-ih i 70ih godina. ${ }^{102}$ Sve što se događalo u Jugoslaviji, ali i socijalističkim zemljama lagera, bilo je posljedica unutarnjih odnosa, ali i pogleda „preko ograde”, na Zapad, Istok, pa i u tzv. Treći svijet. Komunizam se gradio među ostalim i zapadnim idejama, novcem i proizvodima, socijalističke zemlje učile su jedne od drugih, transferi su bili svestrani, a ne jednosmjerni. Sigurno je samo jedno - globalizacija u Istočnoj Europi nije počela tek padom Berlinskoga zida.

\section{Zaključak}

Šime Đodan kroz svoju je produkciju tekstova s ekonomskom tematikom krajem 60-ih i početkom 70-ih godina opsežno tumačio pogreške jugoslavenskoga modela ekonomskoga razvoja te dokazivao da je u takvu kontekstu Hrvatska eksploatirana. To je bilo sasvim u skladu s marksističkom ideologijom u kojoj se samo eksploatirani imaju pravo boriti za vlastite interese. Ipak, u zalaganju za preraspodjelu sredstava od nerazvijenih k razvijenima, od istoka i juga k zapadu i sjeveru, moglo se prozreti i neke (kontra)hegemonističke tendencije. Đodan je bio dio one generacije hrvatskih komunista i intelektualaca koja je u novim uvjetima nastojala „ispregovarati” bolje uvjete za Hrvatsku unutar Jugoslavije. Ali iako je s jedne strane postojala svijest o svekolikim integrativnim procesima, prije svega ekonomskim, na globalnoj razini, izvan čega nije mogla ostati ni Jugoslavija, njezina unutarnja politička i ideološka konstelacija i specifično polje doživljaja uvjetovali su svaku raspravu, pa čak i onu koja bi se željela ogrnuti samo ekonomicističkim ruhom. Naposljetku, političke implikacije uvijek su se svodile na odnos Zagreba i Beograda. No bilo da se taj odnos odvijao konkurentski ili komplementarno, posljedično je zauzimao toliku zapremninu da je morao djelovati hegemono u odnosu na

101 MADŽAR, „Ko koga eksploatiše”, 203.

102 PULA, Globalization Under and After Socialism. 
sve ostale u Jugoslaviji. Drugi sukob odvijao se na osi razvijeni - nerazvijeni, s uvriježenim mišljenjem da bi slobodnija ekonomija i tržište ipak više pogodovali razvijenijim republikama. To je uvjetovalo zahtjeve prema političkoj sferi da ta „slobodna ekonomija”, usto i samoupravna, opet bude zajamčena političko-ideološkim sredstvima, normama i ograničenjima. Bio je to unutarnji jugoslavenski paradoks. Svojevrsna sistemski proklamirana antipolitika koja nije mogla opstati bez čvrste i održive političke konstelacije. ${ }^{103}$

Sukob Šuvara i Đodana ne može se svoditi na sukob između socijalizma i nacionalizma, jugoslavenstva i hrvatstva. Oni sami u tom se periodu nisu odricali nijedne od tih sastavnica. Njihovi nacionalizmi (a ni socijalizmi) nisu bili ni idejno ni diskurzivno čisti, bili su nedosljedni, eklektični, ali još uvijek i inkluzivni. Intimno, Đodan je sigurno bio veći hrvatski nacionalist nego jugoslavenski integralist, što ne znači da su i svi njegovi prijedlozi za „popravljanje" Jugoslavije bili puki cinizam, da te 1969. on i dalje nije vjerovao u mogućnost jugoslavenske i hrvatske sinteze. Ne treba u Đodana iz 1969. učitavati Đodana iz 1971. (kad je već izbačen iz Saveza komunista), ni onoga iz 1972. (kad je bio zatvoren), a pogotovo onoga iz 1990. ili 1991. (kad je bio istaknuti član Hrvatske demokratske zajednice). Pritom ne mislimo da u biografijama kao što su one Šime Đodana i Stipe Šuvara nije bilo kontinuiteta. Dapače, njih su dvojica možda ponajbolji primjer političke dosljednosti vlastitom karakteru. Šime Đodan u osnovi je bio i ostao „narodnjački” tip intelektualca i političara, pa bi se i njegova ekonomska doktrina, nasuprot planskoj realsocijalističkoj ili (neo)liberalnoj, mogla okarakterizirati socijalno-tržišnom i „narodnom”, danas bismo rekli - populističkom. Stipe Šuvar, veliki posvećenik socijalističke ideologije, što ga je često dovodilo do (pa i preko) ruba dogmatizma, cenzorstva, nakon predmetne polemike, odnosno nakon promjene u hrvatskom partijskom rukovodstvu krajem 1971. bit će iduća dva desetljeća u konstantnom političkom usponu, sve do najviših jugoslavenskih partijskih i državnih funkcija, a upravo na vrhuncu političke karijere, krajem 80-ih godina, naći će se na strani povijesno „poraženih”. Povijesni razvoj i događaji nisu potvrdili njegova uvjerenja, ali su ostavili prostora i za skepsu prema uvjerenjima njegovih protivnika, zagovornika tzv. nacionalne panaceje. Svijet s kraja XX. i početka XXI. stoljeća koji se ekonomski globalizira, nacionalno individualizira te usto barem naizgled deideologizira također nije našao čarobni štapić za rješenje brojnih socijalnih, ekonomskih, pa i (među) nacionalnih nepravdi i nejednakosti. Velika klackalica globalnoga i parti-

103 Pojam „antipolitika” zahtijevao bi zasebnu obradu. No jugoslavenski sistem socijalističkoga samoupravljanja, kao konstantni work in progress, pokušaj utapanja države, Partije, nacije u društvo (podruštvljavanje), među ostalim i kroz specifične kardeljevske mješavine („pluralizam samoupravnih interesa”), zapravo se barem dijelom može promatrati i kao preteča intelektualno-disidentskoga koncepta antipolitike koji je u Istočnoj (Centralnoj) Europi postao vid otpora komunističkim establišmentima (državnim socijalizmima) od 70 ih godina, s vrhuncem u 80-ima (Václav Havel, György Konrád i Jacek Kuroń). Vidi npr.: CIŻEWSKA-MARTYNSKA, „The Meaning of the 1980s' Anti-Politics' Legacy within the Contemporary East-Central European Civil Societies”, 37-58. 
kularnoga nastavlja se, bez konačnoga ishoda. Polemika Stipe Šuvara i Šime Đodana podsjetnik je na to da su takve dvojbe opterećivale i protekle generacije, da su one veliku intelektualnu i osobnu energiju ulagale u pokušaj da razumiju svijet i svoje mjesto u njemu, kao i da su u tim pokušajima nerijetko lutale, trudile se pomiriti mnoga protuslovlja, nacionalna, ideološka, društveno-politička. Naposljetku, pripadnici mlađih generacija, kakvi su Šuvar i Đodan bili na zalasku 60-ih i početkom 70-ih godina, borili su se i da osobno dođu do izražaja. Iako su se nadovezali na probleme koje su uvelike naslijedili, trudili su se dati svoj kvalitativni, originalni doprinos, postaviti svoja pitanja i potaknuti javnu raspravu. Time su demonstrirali da je moć ideja nerijetko veća od onih koji ih plasiraju, premda se upravo na njima kao provodnicima, na njihovim osobnim sudbinama, prelamaju uspjesi i neuspjesi tih istih ideja. Čovjek je, ma koliki trag iza sebe ostavio, ipak potrošna roba. Države, sistemi, režimi nastaju i nestaju. Ideje pak, sa svojom sposobnošću transformacije i prilagodbe, mogu biti (gotovo) vječne.

\section{Arhivski i neobjavljeni izvori}

HR-HDA-1002-OFVB: Hrvatska, Hrvatski državni arhiv, Zagreb, fond 1002, Osobni fond Vladimir Bakarić.

HR-HDA-1567-MH: Hrvatska, Hrvatski državni arhiv, Zagreb, fond 1567, Matica hrvatska.

„Međunacionalni ekonomski odnosi”. Interni materijal. Centralni komitet Saveza komunista Jugoslavije, srpanj 1966. [u osobnom posjedu autora].

SR-AJ-507-SKJ: Srbija, Arhiv Jugoslavije, Beograd, fond 507, Savez komunista Jugoslavije.

\section{Objavljeni izvori i tisak}

Borba (Beograd), 1969.

PETROVIĆ, Gajo; SUPEK, Rudi, ur. Jun-lipanj 1968. Dokumenti [zbornik dokumenata o studentskim zbivanjima u Jugoslaviji u junskim danima 1968. godine]. Praxis. Zagreb: Hrvatsko filozofsko društvo, 1971.

Vjesnik (Zagreb), 1969.

\section{Literatura}

ANDERSON, Malcolm. States and Nationalism in Europe Since 1945. London; New York: Routledge, 2000.

BAYLY, Christopher A. The Birth of the Modern World, 1780-1914. Maiden: Blackwell Publishing, 2004.

BEKIĆ, Darko. Jugoslavija u hladnom ratu: odnosi s velikim silama 19491955. Zagreb: Globus, 1988.

BILANDŽIĆ, Dušan. Hrvatska moderna povijest. Zagreb: Golden marketing, 1999. 
BILANDŽIĆ, Dušan. Povijest izbliza. Memoarski zapisi 1945-2005. Zagreb: Prometej, 2006.

BILANDŽIĆ, Dušan. „Slovenija i ostala Jugoslavija - ideja Borisa Kidriča i Edvarda Kardelja”. U: Slovenija v jugoslovanski federaciji. Zbornik Ziherlovi dnevi 1987, ur. Boštjan Markič. Ljubljana: Knjižnica FPSN, 1987, 357-379.

BILLIG, Michael. Banal Nationalism. London: Sage, 1995.

BRLEKOVIĆ, Josip. „Članstvo Matice hrvatske u prošlosti i sadašnjosti”. Matica hrvatska. Pristup ostvaren 12. 7. 2021. https:/www.matica.hr/omatici/ Kratka\%20povijest\%20organiziranja\%20i\%20ustrojstva\%20Mati\%C4\%8Dina\%20\%C4\%8Dlanstva\%20(1842-2014)/.

CIŻEWSKA-MARTYŃSKA, Elżbieta. „The Meaning of the 1980s’ Anti-Politics' Legacy within the Contemporary East-Central European Civil Societies". Intersections. East European Journal of Society and Politics 1 (2015), br. 3: 37-58. Pristup ostvaren 22. 7. 2021. DOI: 10.17356/ieejsp.vli3.103.

CONRAD, Sebastian. Globalisierung und Nation im Deutschen Kaiserreich. München: C.H.Beck Verlag, 2006.

ČALIĆ, Mari-Žanin. Jugoistočna Evropa: globalna historija. Sarajevo: Udruženje za modernu historiju, 2020.

ĐODAN, Šime. „Determinante gospodarskog razvoja primorske Hrvatske”. Dubrovnik (1968), br. 2: 1-9.

ĐODAN, Šime. „Gdje dr Stipe Šuvar 'pronalazi' nacionalizam, a gdje ga ne vidi”. Kolo (1969), br. 7: 686-712.

ĐODAN, Šime. „Gospodarska reforma i izbor optimalnog modela rasta”. Kolo (1968), br. 4: 301-308.

ĐODAN, Šime. „Investicije zapadno od Drine (O napisima nekih dnevnih listova i obavještavanju javnosti)". Kolo (1969), br. 7: 714-717.

ĐODAN, Šime. „Ljetne igre - gospodarske odrednice - povijest”. Dubrovnik (1968), br. 3: 1-43.

ĐODAN, Šime. „Prilog raspravi o regionalnom razvoju u SFRJ”. Kolo (1969), br. 3: 246-254.

ĐODAN, Šime. „Prilog razmatranju predloženih izmjena Ustava SFRJ”. Kolo (1968), br. 11: 471-473.

ĐODAN, Šime. „Problemi razdiobe u našem društvu”. Kolo (1968), br. 3: 194-197.

ECHEVARRIA, Antulio J. Wars of Ideas and the War of Ideas. Carlisle, PA: US Army War College Press, 2008. Pristup ostvaren 10. 7. 2021. https:// press.armywarcollege.edu/monographs/644.

FETZER, Thomas. „Nationalism and Economy”. Nationalities Papers 48 (2020), br. 6: 963-973. Pristup ostvaren 10. 6. 2021. DOI: 10.1017/nps.2019.123.

HAMMETT, Daniel. „From banal to everyday nationalism: narrations of nationhood". Geography 106 (2021), br. 1: 16-24. Pristup ostvaren 15. 7. 2021. DOI: $10.1080 / 00167487.2020 .1862578$. 
HARVEY, David. A Brief History of Neoliberalism. Oxford: Oxford University Press, 2005.

HAYEK, Friedrich A. „The Intellectuals and Socialism”. University of Chicago Law Review 16 (1949), br. 3: 417-433.

HELLEINER, Eric; PICKEL, Andreas, ur. Economic Nationalism in a Globalizing World. Ithaca, NY: Cornell University Press, 2005.

HONGTU, Li. „The return of the history of ideas - Observations on the evolution of research paradigms in the history of ideas". Chinese Studies in History 53 (2020), br. 2: 136-149. Pristup ostvaren 10. 5. 2021. DOI: 10.1080/00094633.2020.1711652.

HORVAT, Branko. Ogled o jugoslavenskom društvu. Zagreb: Mladost, 1969.

JAKIR, Aleksandar. „Nemoguća misija i početak kraja? Gospodarske reforme u SFR Jugoslaviji tijekom 1960ih godina". U: Pogledi 4. Iz hrvatske povijesti 20. stoljeća $=$ Iz hrvaške zgodovine 20. stoletja, ur. Iskra Iveljić, Stjepan Matković i Žarko Lazarević. Ljubljana: Inštitut za novejšo zgodovino, 2012, 91-110.

KALUĐEROVIĆ, Željko. „Poimanje globalizacije”. Filozofska istraživanja 29 (2009), br. 1: 15-29.

LAMPE, John R. Yugoslavia as History: Twice There was a Country. New York: Cambridge University Press, ${ }^{2} 2000$.

MADŽAR, Ljubomir. „Ko koga eksploatiše”. U: Srpska strana rata. Trauma i katarza u istorijskom pamćenju. I deo, ur. Nebojša Popov. Beograd: Samizdat B92, ${ }^{2} 2002,203-233$.

MANDIĆ, Igor. Notes: VUS 1968-1972. Zagreb: Matica hrvatska, 2007.

MAYALL, James. Nationalism and International Society. New York: Cambridge University Press, 1990.

MIHALJEVIĆ, Josip. „Boro Krstulović: Djedovi sukobi s Brozom i Bakarićem”. Hrvatska revija 10 (2010), br. 1: 80-84.

MIHALJEVIĆ, Josip. „Liberalizacija 1960-ih godina - podloga Hrvatskog proljeća". U: Hrvatska i Hrvatsko proljeće 1971. Zbornik radova, ur. Igor Zidić. Zagreb: Matica hrvatska, 2017, 263-277.

MITCHELL, Timothy. „Fixing the Economy”. Cultural Studies 12 (1998), br. 1: 82-101.

MUJADŽEVIĆ, Dino. Bakarić. Politička biografija. Zagreb: Plejada, 2011.

MUJADŽEVIĆ, Dino. „Stavovi Vladimira Bakarića o centralističkoj opoziciji (1966-1969)". Tokovi istorije (2012), br. 2: 40-63.

NAIRN, Tom. Faces of Nationalism: Janus Revisited. London: Verso, 1997.

NOVE, Alec. The Economics of Feasible Socialism. London; Boston: Allen and Unwin, 1983.

OSTOJIĆ, Stevo. Javni dnevnik. Zagrebački kulturni i društveni horizonti 1952-1983. Zagreb; Beograd: Globus; Prosveta, ${ }^{2} 1984$. 
PICKEL, Andreas. „Explaining, and Explaining with, Economic Nationalism". Nations and Nationalism 9 (2003), br. 1: 105-127.

POULANTZAS, Nicos. Classes in Contemporary Capitalism. London: New Left Books, 1975.

PRYKE, Sam. „Economic Nationalism: Theory, History and Perspective”. Global Policy 3 (2012), br. 3: 281-290.

PULA, Besnik. Globalization Under and After Socialism The Evolution of Transnational Capital in Central and Eastern Europe. Redwood City: Stanford University Press, 2018.

RAMET, Sabrina P. Nationalism and Federalism in Yugoslavia, 1962-1991. Bloomington; Indianapolis: Indiana University Press, ${ }^{2} 1992$.

RAMET, Sabrina P. The Three Yugoslavias. State Building and Legitimation, 1918-2005. Washington, DC; Bloomington: Woodrow Wilson Center Press; Indiana University Press, 2006.

ROBERTSON, Roland. Globalization: Social Theory and Global Culture. London: Sage, 1992.

RUSINOW, Dennison. Yugoslav Experiment 1948-1974. Berkley; Los Angeles: University of California Press, 1978.

ŠUVAR, Stipe. „Da li je Hrvatska eksploatirana”. Naše teme (1969), br. 12: 2002-2066.

ŠUVAR, Stipe. „Društveni razvoj i međunacionalni odnosi u tumačenjima dra Šime Đodana”. Naše teme (1969), br. 6: 994-1019.

ŠUVAR, Stipe. Socijalizam i nacije, sv. 2. Zagreb: Globus, 1988.

THOMPSON, Edward P. „Socialism and the Intellectuals”. U: E. P. Thompson and the Making of the New Left: Essays \& Polemics, ur. Cal Winslow. New York: Monthly Review Press, 2014, 89-101.

TOOZE, Adam. „Imagining National Economies: National and International Economics Statistics 1900-1950”. U: Imagining Nations, ur. Geoffrey Cubitt. Manchester: Manchester University Press, 1998, 212-228.

URRY, John. „Towards a Structural Theory of the Middle Class”. Acta Sociologica 16 (1973), br. 3: 175-187. Pristup ostvaren 10. 7. 2021. DOI: 10.1177/000169937301600302.

WEISS, Linda. „Introduction: bringing domestic institutions back in”. U: States in the Global Economy: Bringing Domestic Institutions Back In, ur. Linda Weiss. Cambridge: Cambridge University Press, 2003, 1-34.

WICKBERG, Daniel. „Intellectual History vs. the Social History of Intellectuals". Rethinking History 5 (2001), br. 3: 383-395. Pristup ostvaren 5.7. 2021. DOI: 10.1080/13642520110078505. 


\section{SUMMARY}

\section{The Public Polemic of Stipe Šuvar and Šime Đodan of 1969 as an Example of a Struggle of Ideas in a (Trans-)National Context}

This paper examines the cause, flow, and context of the intellectual and political debate between Stipe Šuvar and Šme Đodan that took place during 1969, in the conditions of socio-political, cultural, and economic turmoil in the then socialist Croatia and Yugoslavia. The main question that was explicitly and implicitly present throughout the debate was: 'Is Croatia being exploited in Yugoslavia?' This discussion, however, was multi-layered and more complex than that. In it, the authors touched upon the relationship between nationalism and inter-ethnic economic integration within Yugoslavia as well as the integration of Yugoslavia with the world, the relationship between economy and culture, emotional and rational arguments in the political and economic spheres, nationalism and demographics, modernisation and national/ ethnic emancipation, the interaction of processes in the eastern, socialist bloc and in the West, and the consequences that Yugoslavia should draw from them. As a consequence of this more complex interpretation, their opposed positions (struggle of ideas) cannot be reduced to a simple dichotomy such as socialism-nationalism and Croatianness-Yugoslavness. Furthermore, the freer speech that became predominant in Yugoslav and Croatian public space in the 1960s and 1970s made it easier to cross the borders between the economic, political, social, and cultural spheres. The economic dimension of nationalism would prove inseparable from the national discourse, and it would become apparent that it could not be adequately addressed through general debates in the field of economic theory and practice alone. Finally, the Šuvar-Đodan polemic is a reminder of the reflections on globalisation that were then taking place in socialist societies and states, and which had begun long before the fall of the Berlin Wall.

Key words: Yugoslavia; Croatia; Šime Đodan; Stipe Šuvar; nationalism; socialism; globalism 